\title{
Systematic Review \\ Role of Lipopolysaccharide, Derived from Various Bacterial Species, in Pulpitis-A Systematic Review
}

\author{
Aniela Brodzikowska ${ }^{1}$, Monika Ciechanowska ${ }^{2}$, Michał Kopka ${ }^{2,3}$, Albert Stachura ${ }^{2,3}$ and Paweł K. Włodarski ${ }^{2, *}$ (D) \\ 1 Department of Conservative Dentistry, Medical University of Warsaw, 02-091 Warszawa, Poland; \\ aniela.brodzikowska@wum.edu.pl \\ 2 Department of Methodology, Medical University of Warsaw, Żwirki i Wigury 61, 02-097 Warszawa, Poland; \\ nika.ciechanowska@gmail.com (M.C.); m_kopka@wp.pl (M.K.); albert.stachura@wum.edu.pl (A.S.) \\ 3 Doctoral School, Medical University of Warsaw, 02-091 Warszawa, Poland \\ * Correspondence: pawel.wlodarski@wum.edu.pl
}

Citation: Brodzikowska, A.; Ciechanowska, M.; Kopka, M.; Stachura, A.; Włodarski, P.K. Role of Lipopolysaccharide, Derived from Various Bacterial Species, in Pulpitis-A Systematic Review. Biomolecules 2022, 12, 138. https:// doi.org/10.3390/biom12010138

Academic Editor: Lenka Šindlerová

Received: 7 December 2021

Accepted: 11 January 2022

Published: 15 January 2022

Publisher's Note: MDPI stays neutral with regard to jurisdictional claims in published maps and institutional affiliations.

Copyright: (C) 2022 by the authors. Licensee MDPI, Basel, Switzerland. This article is an open access article distributed under the terms and conditions of the Creative Commons Attribution (CC BY) license (https:// creativecommons.org/licenses/by/ $4.0 /)$.

\begin{abstract}
Lipopolysaccharide (LPS) is widely used for induction of inflammation in various human tissues, including dental pulp. The purpose of this study was to summarize current medical literature focusing on (1) cell types used by researchers to simulate dental pulp inflammation, (2) LPS variants utilized in experimental settings and how these choices affect the findings. Our study was conducted in accordance with the Preferred Reporting Items for Systematic Reviews and Meta-Analyses (PRISMA). We searched for studies reporting outcomes of lipopolysaccharide application on dental pulp cells in vitro using electronic databases: MEDLINE, Web of Science and Scopus. Having gathered data from 115 papers, we aimed to present all known effects LPS has on different cell types present in dental pulp. We focused on specific receptors and particles that are involved in molecular pathways. Our review provides an essential foundation for further research using in vitro models of pulpitis.
\end{abstract}

Keywords: LPS; pulpitis; inflammation; pulp cells

\section{Introduction}

Pulpitis is an inflammation of the dental pulp - a painful condition mostly caused by Gram-negative bacteria. Lipopolysaccharides, which are components of the Gram-negative bacterial outer membrane, take part in inducing inflammation in the dental pulp. Understanding mechanisms underlying this pathology may help find novel specific treatments.

\subsection{Cells in Dental Pulp}

Dental pulp is a loose connective tissue of ectomesenchymal origin, enclosed by three mineralized materials: dentin, enamel, and cementum [1]. It consists various cells: fibroblasts, odontoblasts, macrophages, mast cells and plasma cells [2]. The odontoblast layer lying on the periphery, at the interface of dentin-pulp complex, is responsible mainly for dentin development [2]. Channels created by odontoblasts extend through dentin and provide nutrient to avascular dentin [2]. Beneath the odontoblast layer lies the cell-poor zone (zone of Weil) [2] and underneath-a cell-rich zone, filled with fibroblasts and undifferentiated mesenchymal cells [2]. At the core, the central pulp contains numerous fibroblasts, vessels and autonomic and sensory nerves, which extend to peripheral layers [2].

\subsection{Pulpitis}

Pulp inflammation is a dynamic and complex process involving neural, vascular and immunological reactions. Microorganisms, dentinal tubules of the teeth, chemical or mechanical irritation, as well as trauma may induce this state [1].

Bacterial infection is the most frequent cause of pulp diseases. Pulp inflammation is primarily the result of cooperation between anaerobic bacteria (such as Porphyromonas 
gingivalis, Prevotella intermedia, Fusobacterium nucleatum and Treponema denticola) [3] and other Gram-negative bacteria [4]. Thus far, bacteria species have not been correlated with a specific clinical symptomatology [3]. The pulpitis can be reversible when it subsides after treatment, or irreversible when healing is not possible [2].

\subsection{Lipopolysaccharide}

Lipopolysaccharides are components of the outer membrane of Gram-negative bacteria, composed of a hydrophobic domain-endotoxin-lipid A, hydrophilic O-antigen and core polysaccharide [5]. The most bioactive LPS element is lipid A [5]. LPS by binding to cell surface receptors, such as Toll-Like Receptor 4 (TLR4)/Cluster of Differentiation 14 (CD14)/Myeloid Differentiation factor 2 (MD2), induces the production and secretion of proinflammatory cytokines, nitric oxide and eicosanoids [5]. LPS is used in research to induce inflammation in human dental pulp cells in vitro.

Here we review types of LPS used in research and the mechanisms underlying their effect on different cell types-especially human dental pulp cells (hDPCs), human dental pulp stem cells (hDSPCs), fibroblasts and odontoblasts.

\section{Materials and Methods}

This study was conducted in accordance with the Preferred Reporting Items for Systematic Reviews and Meta-Analyses (PRISMA) guidelines, using a previously designed protocol (Supplementary File S1). We searched for studies reporting outcomes of lipopolysaccharide influence on dental pulp cells in vitro. All articles written in English, except for reviews, letters, and editorials, were included.

We searched using electronic databases: MEDLINE, Web of Science and Scopus. To identify all relevant articles, we used prespecified search engines for each database (Figure 1 , Supplementary File S1). Additionally, we screened references of selected articles to find papers not identified in the primary search. The systematic search of the literature was performed by M.C. and M.K. independently in October 2021.

\subsection{Study Selection}

Each relevant publication was categorized, based on cellular cultures, interventions used and outcomes. Articles were included based on predefined selection criteria: appropriate design (LPS use in induction of inflammation in vitro), reporting of the outcomes and a defined cellular culture. Exclusion criteria were in vivo studies, reviews, letters and editorials, inadequate design, and a substantial lack of methodology.

Study eligibility was assessed by screening titles and if necessary, abstracts. Later, full texts were assessed for inclusion and exclusion criteria. All disagreements were resolved by a consensus between the two reviewers (M.C. and M.K.).

\subsection{Data Extraction and Analyses}

The following information was extracted from each study by M.C and M.K: LPS type, cellular culture type and outcomes. Strengths and weaknesses of selected studies were appraised in the discussion.

We did not perform quantitative statistical analysis of selected studies because of methodological and clinical heterogeneity. A systematic review of the outcomes was undertaken instead. 


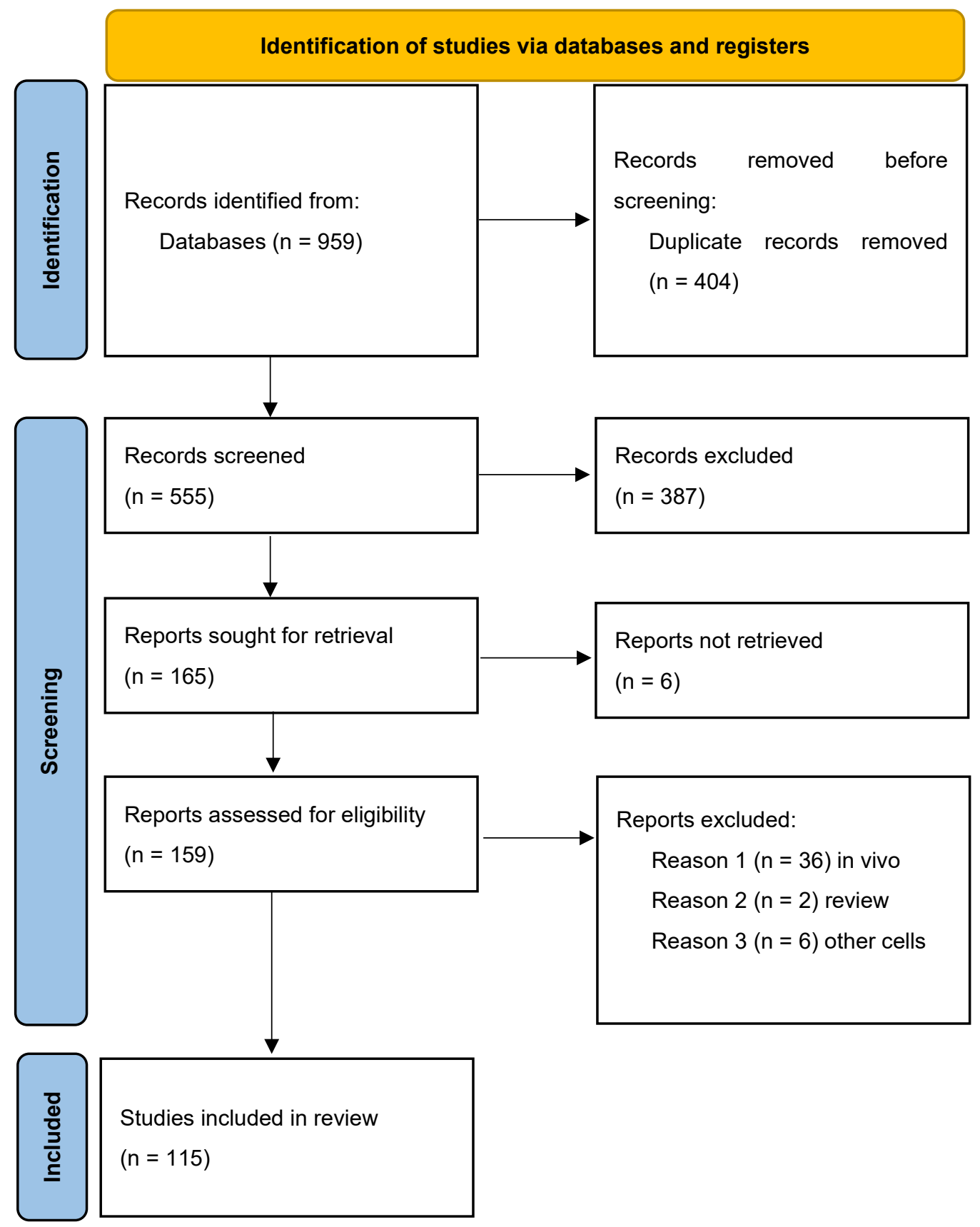

Figure 1. PRISMA flowchart describing data collection for this study.

\section{Results}

\subsection{Escherichia coli LPS}

\subsection{1. hDPCs}

$E$ coli LPS was used in the most investigated studies. It induces cytokine expression: Interleukin $1 \beta$ (IL-1 $\beta$ ), IL-6, IL-8 and tumor necrosis factor $\alpha$ (TNF- $\alpha$ ) and extracellular matrix-associated proteins: matrix metalloproteinases (MMPs) [6], vascular cell adhesion molecule 1 (VCAM-1) and Intercellular Adhesion Molecule 1 (ICAM-1). The above-mentioned changes are mediated by TLR4 receptor activation and nuclear factor kappa-light-chain-enhancer of activated B cells (NF-kB) pathway.

Some studies found alternations in transcriptional factors upon LPS stimulation. One of upregulated proteins is ten-eleven translocation 2 (TET2) DNA methylcytosine dioxygenase [7], responsible for hydroxymethylation of e.g., Myeloid differentiation primary response 88 (MyD88) gene and promoting its expression. LPS stimulation also upregulates 
octamer-binding transcription factor 4-B1 (OCT4B1) leading to overexpression of OCT4B [8]. Both particles protect hDPCs from apoptosis [9]. Silencing OCT4B1 changes the expression of 38 microRNAs [8]. Upon inflammation onset, DNA methyltransferase 1 (DNMT1) expression diminished, leading to changes in methylation of IL-6 and TNF-receptor-associated factor-6 (TRAF6) promoters, thus activating NF- $\mathrm{kB}$ and mitogen-activated protein kinase (MAPK) pathways [10]. A similar pro-inflammatory effect is observed when using 5-Aza2'-deoxycytidine (5-Aza-CdR), which inhibits methyltransferases [11].

LPS may regulate noncoding RNA particles. The maternally expressed gene 3 (MEG3) particle belonging to long non-coding RNA (lncRNA) group is induced in inflamed dental pulp and LPS-treated cells. Knocking down this lncRNA stopped proinflammatory proteins expression, possibly by disturbing the p38/MAPK signaling pathway [12]. MEG3 depletion promoted odontogenic differentiation of hDPCs via Wnt/ $\beta$ catenin pathway [12]. Another IncRNA group member, upregulated by LPS, is NUTM2A antisense RNA 1 (NUTM2AAS1) [13]. Silencing its target-let-7c-5p-promotes High-Mobility Group Box 1 (HMGB1) expression [13]. This protein decreases viability and proliferation of hDPCs [14] but promotes cellular migration [13]. LPS-induced inflammation is also regulated by microRNAs. Overexpression of microRNA-21-5p mitigates activation of NF- $k B$ and cytokine expression-an effect likely mediated by targeting UTR region of TRAF6, which is a part of TLR4 transduction pathway [15].

LPS induces reactive oxygen species (ROS) production [16] and downregulates ROSscavenging protein peroxisome proliferator-activated receptor $\gamma$ (PPAR $\gamma$ ). Subsequent activation of NF-KB and ERK1/2 increases expression of VCAM-1, ICAM-1 and MMPs [17,18]. Rosiglitazone (PPAR $\gamma$ agonist) attenuates proinflammatory state by reducing cellular NO activity and ROS formation [17]. LPS also upregulates astrocyte elevated gene-1 (AEG-1) and activates nuclear translocation of p65 [19]. Hypoxia-inducible factor $1 \alpha(\mathrm{HIF}-1 \alpha)$ plays a double role in inducing inflammation. Its overexpression leads to increased IL- $1 \beta$ and TNF- $\alpha$ production [20]. At the same time, HIF-1 $\alpha$ downregulates IL-6 [21]. This phenomenon occurs because HIF- $1 \alpha$ activates the suppressor of cytokine signaling 3 (SOCS3), which leads to downregulating CCAAT enhancer-binding protein beta $(\mathrm{CEBPb})$. Since $\mathrm{CEBPb}$ is an inducer of IL-6, hence the net result is IL-6 downregulation [21].

E. coli LPS-induced pulpal cells are also used as a model for searching potential antiinflammatory compounds. One such compound is involved in apoptosis regulation. Sirtuin 6 (SIRT6) belonging to NAD+-dependent deacetylases, regulates Ku70 acetylation [22]. Overexpression of SIRT6 leads to deacetylation of Ku70, interrupting mobilization of an apoptosis inductor-Bax protein [22]. The second compound group is associated with autophagy. LPS decreases levels of autophagy mediators-autophagy related 5 protein (ATG-5), Beclin-I, microtubule-associated protein 1A/1B light chain 3 (LC3-I/II), mitochondrial biogenesis molecules heme oxygenase-1 (HO-1) and peroxisome proliferator-activated receptor gamma coactivator 1-alpha (PGC-1 $\alpha)$ [23]. Schisandrin $C$ is a natural product extracted from Schisandra chinensis, commonly used in Chinese medicine. This compound restores the expression of the above-mentioned proteins [23]. Schisandrin $C$ activates autophagy, leading to osteoblastic differentiation of hDPCs, mediated by upregulated dentin matrix acidic phosphoprotein 1 (DMP-1), dentin sialophosphoprotein (DSPP), Bone morphogenetic protein 2 (BMP-2) and BMP-7 [23]. Davallialactone [24] (hispidin analogue), produced by the mushroom Inonotus xeranticus, is a potent antioxidant [25]. Davalillialactone decreases ROS activity in LPS-stimulated cells [24]. It also inhibits nuclear translocation of NF- $\mathrm{B}$ and ERK1/2 activity and mitigates expression of proinflammatory particles i.e., MMP-2, MMP-9, VCAM-1, ICAM-1, inducible nitric oxide synthases (iNOS) and cyclooxygenase (COX2) [24]. A similar mechanism of action is presented by teneligliptin, dipeptidyl peptidase-4 inhibitor [26]. It decreases production of 4-Hydroxynonenal (4-HNE) from lipid peroxidation, which can represent ROS activity. Teneligliptin also reduces expression of TLR4 [26]. Another study showed that hDPCs treated with NAC (N-acetylcysteine), combined with Biodentine or Mineral trioxide aggregate (MTA) (cement compounds used in 
pulpitis treatment) [27], showed better viability. The group with MTA and NAC treatment also promoted mineralization [27].

A significant group of anti-inflammatory compounds is related to inhibition of NF- $\kappa B$ pathway. Fluocinolone acetonide (FA) is a steroidal anti-inflammatory drug [28]. In LPSstimulated cells it reduces expression of IL-1 $\beta$, IL- 6 and IL- 8 and up-regulates odontoblastic markers-alkaline phosphatase (ALP), Runt-related transcription factor 2 (RUNX2) and DSPP [28]. FA also increases PPAR $\gamma$ mRNA expression by inhibiting the expression of phosphorylated-NF-kB P65 and triggering activator protein-1 (AP-1) [28]. Another study by Wang et al. showed that betamethasone (steroid), added to LPS-treated cells, reduces expression of IL-1 $\beta$, IL- 6 and TNF- $\alpha$ and promotes mineralization markers-ALP, DSPP and osteocalcin [29]. Simvastatin, a lipid-lowering medication, significantly reduces LPS-stimulated production of IL-1 $\beta$, IL-6, VCAM-1 and ICAM-1 [30]. It also decreases expression of $\mathrm{p} 65$, its phosphorylation and nuclear translocation. Simvastatin mitigates phosphorylation of I-KB [30] —an effect also observed for P. gingivalis LPS.

Nel-like molecule type 1 (Nell-1) is a compound used as an osteoinductive factor. Human recombinant Nell-1 attenuates p38 and ERK MAPK pathways and decreases expression of IL-6 and IL-8 in LPS-stimulated cells [31].

Bromelain is a natural product, containing various bioactive substances e.g., thiol endopeptidases, phosphatase, glucosidase, peroxidase, cellulase, and several protease inhibitors and is obtained from pineapple (Ananas comosus) stems and fruits [32]. It decreases IL-1 $\beta$, IL-6, IL-8, ICAM-1 and VCAM-1 by reducing phosphorylation of p65, ERK and p38. It also promotes ALP activity and formation of mineralized nodules [33]. A similar effect is exerted by terrein [34]. This Penicillum sp. bioactive metabolite reduces production of VCAM-1 and ICAM-1 by blocking the activation of Akt and suppressing NF- $\mathrm{KB}$ [34].

Catechins-polyphenols derived from green tea have an anti-inflammatory potential [35]. Epigallocatechin-3-gallate (EGCG) and epicatechin gallate (ECG) reduce production of IL-6, IL-8, VCAM-1, ICAM-1, VEGF and COX-2, induced by LPS [36,37].

Acemannan, a polysaccharide from Aloe vera induces proliferation, differentiation, growth factor and ECM synthesis and formation of mineralized bridge [38].

Huang et al. showed that hDPCs treated with LPS and co-stimulated with odontogenic induction medium had increase ALP activity, DSPP DMP-1 via NF- $\kappa$ B and no change in c-Jun expression [39].

LPS stimulates production of IL-1 $\beta$, IL-6. After 14 days, cultured cells presented markers of dentinogenesis. Wnt5a, Runx2 and ALP proteins were upregulated, and ALP activity was increased on the 21 st day. Wnt 5 activation was confirmed by using inhibitorBox5, which attenuated Runx2 and ALP levels [40].

\subsubsection{Fibroblasts}

E. coli LPS was used in 7 out of 13 experiments performed on human pulp fibroblasts. Bacteria serotypes were specified in 5 articles-E. coli 055:B5 in 2, L-2880 in 1, 0111:B4 in 2.

E. coli LPS stimulates the production of pro-inflammatory factors: CCL2, IL-8 and IL-6 [41]. Less intense upregulation occurs for IL-4, GCFS, GM-CSF and CCL5, as well as for IL-1 $\beta$, IL-10, IL12p70, IL-17A, TNF- $\alpha$, INF- $\lambda$ [41] and TNF $\beta$ [42]. The maturation and release of IL- $1 \beta$ is stimulated by a combination of LPS and ATP. This effect is mediated by stimulating the pyrogenic P2X7 ATP-gated ion channel and subsequent activation of the NLRP3/caspase-1 pathway [42,43]. The process involves two steps: (1) activation of TLR4/MyD88/NF- $\varkappa \mathrm{B}$ pathway by LPS resulting in up-regulation of NLRP3 and expression of pro-IL-1 $\beta$ genes, and (2) ATP-stimulated ROS production is the second signal for NLRP3 activation [44]. E. coli LPS stimulates COX-2, but not COX-1 [45].

MicroRNAs take part in the posttranscriptional regulation of gene expression. LPS stimulation increases expression of miR-146a (the miRNA precursor) in gingiva fibroblasts, periodontal ligament fibroblasts and dental pulp cells, upregulating KBTBD7 (gene encoding a transcriptional activator) and downregulating miR-21 and miR-155 [46,47]. 
Considering inflammation, methyl mercaptan $(\mathrm{CH} 3 \mathrm{SH})$ acts synergically with LPS, stimulating IL-6 production [42]. Exogenous melatonin causes an opposite effect via suppression of COX-2 and IL- $1 \beta$ [45]. Berberine reduces IL- $1 \beta$, IL- 6 and TNF- $\alpha$ expressions, proliferation and miR-21 expression, inhibiting inflammatory response $[47,48]$.

\subsubsection{Odontoblasts}

E. coli LPS was used in four out of eight experiments with odontoblast-like cells. Serotypes were specified in three articles-E. coli 055:B5, E. coli k-235 strain LPS and E. coli L-2880.

Two receptors-TLR4 and CD14-bind LPS on the surface of odontoblasts [49]. LPS stimulation results in IL-8 mRNA and protein expression [50]. Binding to TLR4 upregulates VEGF (regulator of angiogenesis) expression in odontoblasts [49]. It can be associated either with regeneration of the pulp-dentinal complex or with necrosis caused by vessel collapse [49]. Odontoblasts are involved in alleviating inflammation in surrounding tissues. In response to LPS, they produce secretory leukocyte protease inhibitor (SLPI), which inhibits the activation of NF-kB and antagonizes LPS response [51]. Both mechanical injury and LPS stimulation are associated with similar Notch signaling pathway activation, which prompts differentiation of precursor cells to odontoblast-like cells [52]. This mechanism protects against injury, prevents apoptosis, enhances cell survival and maturation [52]. LPS induces inflammatory cytokines and chemokines in odontoblast-like cells, macrophages and osteoclasts. Propolis decreases production of IL-1a, MIP-1a, IL-12(p70) and IL-15 in odontoblast-like cells; MIP- $1 \alpha$, G-CSF, TNF- $\alpha$ and IL-6 in macrophages and MIP- $1 \alpha$ production in osteoclasts [53].

A study of Liao et al. investigated the role of sclerostin in LPS induction. Upon LPS stimulation, production of sclerostin increased, impairing odontoblastic differentiation. Sclerostin activates NF-kB pathway, upregulating expression of IL-6, IL-8, IL-1 $\beta$, ICAM-1, VCAM-1, CXCR4, MCP-1, VEGF, VEGFR-1 and PIGF [54].

\subsubsection{DPSCs}

E. coli LPS was used in 12 out of 25 experiments performed using dental pulp stem cells (DPSCs). Serotypes were specified in 6 articles-E. coli 055:B5 in two, L-2880 in one, 0111:B4 in three articles.

Bindal et al. (2018) concluded that treating hDPSCs cells with $1 \mu \mathrm{g} / \mathrm{mL}$ E. coli LPS for $24 \mathrm{~h}$ is the most appropriate approach to inducing an inflammatory microenvironment, based on IL-6, IL-8, tPA and TAC1 levels [55]. LPS alone did not promote production of IL-6 in the initial phase (after $48 \mathrm{~h}$ ), but after 7 days, rising LPS concentrations significantly increased secretion of Il-6 [56]. IL-1 $\alpha$ level was increasing proportionally to LPS concentrations, suggesting a progressive onset of inflammation [55]. Uncontrolled overexpression of IL-1 $\beta$ may be the primary force driving the inflammation's severity and causing pulp necrosis [57]. Interestingly, the level of TNF $\alpha$ was significantly increased despite a lack of genetic expression. This phenomenon could be explained by inflammation initiation by E. coli LPS via a dual pathway-TLR4 and TLR2 [55].

Innate immune response, especially mediated by macrophages, is modulated in DPSCs through the TNF- $\alpha /$ IDO axis [57]. LPS-induced TLR4 activation leads to NF- $\mathrm{KB}$ p65 translocation into the nucleus, with subsequent expression of iNOS, COX-2 and inflammatory mediators, such as TNF- $\alpha$. The expression of the NF- $\mathrm{kB}$ subunit $\mathrm{p} 65$ is partially blocked by DPSCs and reduces TNF- $\alpha$ production by macrophages. IDO expression levels in DPSCs are increased after LPS or TNF- $\alpha$ stimulation in a time-dependent manner [57]. These mechanisms may be associated with an anti-inflammatory effect of DPSCs.

\section{Differentiation}

Wnt5a induces mesenchymal stem cells osteogenesis and suppresses adipogenesis; plays a role in tooth development and odontoblast differentiation [58]. It also upregulates inflammatory cytokines e.g., IL-6, IL-8 and IL-1b activating the non-canonical pathway [58]. LPS can enhance Wnt5a expression in a time and dose-dependent manner in hDPSCs-an 
effect mediated by TLR4/MyD88, PI3K/AKT and NF-kB signaling pathways [58]. LPS promotes mRNA expression of genes related to mineralization, such as OCN, DSPP, ALP and BSP in DPSCs obtained from rats and this effect declines with age [59]. LPS inhibits osteogenic differentiation of DPSCs via HMGA2/PI3K/Akt pathway [60].

He et al. (2014) [61] demonstrated that odontogenic differentiation was associated with TLR4 activation by LPS in hDPSCs. They also proved that activation of p38 mitogenactivated protein kinase (MAPK) and extracellular signal-regulated kinase (ERK), but not NF- $\kappa$ B, signaling pathways are involved in LPS-mediated differentiation of hDPSCs [61]. LPS alone promotes the migration of DPSCs, however 4-Methylumbelliferone (4-mu) can further accelerate the migration and odontogenetic differentiation by downregulating the expression of inflammatory cytokines [62].

Tissue-committed stem cells (TCSCs) migrate to injury sites and differentiate there, prompted by stromal cell-derived factor -1a (SDF-1a)/CXC chemokine receptor 4 (CXCR4) axis [63]. Secretion of SDF-1 may be enhanced (directly by LPS) or suppressed (indirectly by inflammatory cytokines) [63]. Inducing cells with LPS increased the production of CXCR4 [63]. Both SDF-1 and CXCR4 are regulated by hypoxia [63].

Senescence

LPS-treated DPSCs age faster-they have a flat shape, increased size and disordered F-actin, surrounding the nucleus [64]. Upon LPS stimulation, levels of senescence markers, e.g., $\beta$-galactosidase (SA-b-gal) rise in dose-dependent manner [65] - a finding associated with TLR4/MyD88-NF-kB-p53/p21 signaling pathways [65]. p65 knockdown weakens the NF- $\kappa B$ signal and reverses the senescence of DPSCs by enhancing the proliferation [65].

Another mechanism involved in cellular senescence is DNA damage. Excess ROS cause oxidative DNA damage (increased $\gamma$-H2A.X expression-a sensitive marker for DNA damage $[64,66])$, also directly activating p16INK4A expression, stopping the cell cycle [64]. LPS induces double strand breaks and subsequent DNA damage [66]. Two main classic DNA repair pathways in eukaryotic cells are homologous recombination (HR) and non-homologous end joining (NHEJ). The mRNA and protein expression levels of Ku70 and Xrcc4 involved in NHEJ, and Rad51 in HR, are increased in LPS-treated DPSCs [66]. Inhibiting Ku70 promotes the p53 pathway apoptosis [66].

LPS has a diverse effect on cell viability, defined as active cell metabolism. Some authors suggest it reduces cell viability [55], while others postulate it has no such effect [56]. Nonetheless, LPS treatment decreases cell survival by increasing apoptosis and necrosis rates [56]. LPS promotes proliferation of DPSCs by increasing TLR4 expression and through HMGA2/PI3K/Akt pathway [59,60].

Some agents act antagonistically to E. coli LPS in hDPSCs. 4-Methylumbelliferone (4-mu) downregulates the expression of inflammatory cytokines (decreased CD44 expression, preventing LMW HA-TLR4-CD44 complex formation) and facilitates cell differentiation [62]. Epigallocatechin gallate (EGCG) has an anti-inflammatory effect, not affecting cell proliferation or differentiation [67]. Betamethasone blocks NF- $\kappa B$ activation, alleviating inflammation and has osteo-/odonto-inductive effects on DPSCs [68]. Let-7c-5p could suppress the inflammatory phenomena and restore the osteogenic differentiation potential of inflamed DPSC via HMGA2/PI3K/Akt pathway [60].

As mentioned before, simvastatin presents anti-inflammatory features in hDPCs. It alleviates inflammation by downregulating TNF- $\alpha$, IL-1 $\beta$ and MMP-9 [69]. It also increases the production of PPAR $\gamma$, which is inhibited by LPS. Constructs of nanofibrous poly(L-lactic acid) scaffolds with simvastatin trigger expression of proteins characteristic for odontoblastic differentiation [69]. This effect is mediated via phosphorylation of ERK1/2 and Smad1 [69].

\subsection{Porphyromonas gingivalis LPS}

3.2.1. hDPCs

P. gingivalis LPS was used in seven studies. 
LPS may influence global gene expression not only via TLRs activation, but also by changing the DNA methylation profile. P. gingivalis LPS downregulates mRNA level of DNA methyltransferase 3B (DNMT3B) and both mRNA and protein levels of DNA methyltransferase 1 (DNMT1) [70]. DNMTs inhibitor-5-Aza-CdR was used in these studies. Deregulation of above-mentioned particles increases levels of proinflammatory mediators and changes microRNAs expression [70]. The most significant change is the upregulation of miR-146a-5p, associated with pulp inflammation [71]. DNMT1 knockdown results in a similar methylation pattern of MIR146A promoter as obtained using 5-Aza$\mathrm{CdR}$ [70]. LPS also induces the expression of methyltransferase-like 3 (METTL3) and extends the level of methylation at the N6 position of adenosine(m6A) [72]. Silencing METTL3 decreases the level of proinflammatory cytokines and inhibits NF- $k$ B pathway. m6A and METTL3 regulate splicing of mRNA. Depletion of METLL3 causes production of MyD88 splice variant, which interrupts the TLR pathway [72].

IFN $\beta 1$ plays an essential role in inflamed cells. LPS stimulation increases NOD-like receptor family pyrin domain containing 6 (NLRP6), caspase 1 (Casp1) and Caps 4 expression, preceded by up-regulation of IFN-B and activation of IFNAR1 receptor [73]. Blocking this receptor cuts the signalization pathway. Similarly to previously-mentioned caspases, Casp3 is upregulated upon LPS stimulus [74], leading to mitigating SIRT6 expression. SIRT6 regulates deacetylation of Ku70, protecting against apoptosis [74]. Vascular endothelial growth factor (VEGF) and SIRT1 are upregulated after LPS stimulation [75]. It leads to activating angiogenesis, enhanced production of MMP-2 and MMP-9, induced migration, and formation of tube-like structures [75]. These processes are promoted by MAP kinases (p38, ERK, JNK), NF-KB and PIK3 pathways [75]. Muramyle dipeptide, which activates nucleotide binding oligomerization domain (NOD) 2, acts synergically with TLR2 and TLR4, enhancing expression of inflammatory particles e.g., human Beta-defensin 2 or COX2, prostaglandin E2 (PGE2), TNF- $\alpha$, IL-6 and IL-8 [76].

An anti-inflammatory potential of several compounds were verified using P.gingivalis LPS. GV1001 oligopeptide is a molecule similar to a part of human reverse transcriptase subunit of telomerase (hTERT), which is a potential target for cancer vaccines [77]. GV1001 decreases LPS-induced phosphorylation of ERK and p38 MAPK, inhibiting TNF- $\alpha$ and IL-6 production [78]. Previously mentioned EGCG and ECG downregulate secretion of TNF- $\alpha$, IL-1 $\beta$, and IL-6 by lowering p65 expression [79]. Cells treated with glutamine show downregulated iNOS and COX2 expression, as well as NO, PGE2, IL-1 $\beta$, TNF- $\alpha$, and IL-8 production [80]. These changes occur via attenuating ERK, p38 and JNK phosphorylation, impairing nuclear translocation of NF- $\mathrm{KB}$ and upregulating MAPK-1, which is an inhibitor of ERK kinase [80]. Platelet-rich fibrin extract (PRFe) - a concentrate of platelets with blood constituents - contains a variety of growth factors that may be helpful in regeneration processes [81]. In vitro studies show PRFe mitigates IL-1 $\beta$ IL-6, IL-8, VCAM-1 and ICAM-1 production [82]. It also upregulates odontoblastic proteins-DSPP, dentin matrix acidic phosphoprotein 1 and activates ALP [82].

\subsubsection{Fibroblasts}

Two studies examined how $P$. gingivalis LPS affects pulp fibroblasts. Only IL-8 (among IL-1b, IL-6, IL-8 and TNF- $\alpha$ measured) was detectable in LPS-stimulated fibroblasts, secreted in a time- and dose-dependent manner [83]. MicroRNA-181 family controls inflammation by regulating growth, development and activation of cells. In LPS-induced fibroblasts, miR-181a expression decreases in a time- and dose-dependent manner, miR$181 \mathrm{~b}$ expression is barely detectable and miR-181c is absent [83]. LPS enhances chemokine (C-C motif) ligand 3 (CCL3) production in fibroblasts from permanent and deciduous teeth, whereas C-X-C motif chemokine 12 (CXCL12) production is elevated only in fibroblasts from deciduous teeth [84]. CCL3 and CXCL12 take part in leukocytes' recruitment and activation in acute inflammation. 


\subsubsection{DPSCs}

LPS activates NF- $\mathrm{kB}$ signaling pathway in dental pulp stem cells, but its binding activities disappear by $60 \mathrm{~min}$ [85].

\subsection{Other Groups}

\subsection{1. hDPCs}

Nakane et al. [86] postulated that there are differences between E. coli's LPS and LPS produced by P. gingivalis, P. endodontalis and F. nucleatum. The one by E. coli inhibits cell protein production more potently than other types. All types of LPS induce DNA production by dental pulp cells [86]. Different types of LPS exacerbate the inflammation, inducing expression of pro-inflammatory cytokines. IL- $1 \beta$ production was enhanced by $P$. endodontalis LPS in cultured human gingival fibroblasts and monocytes from patients with periodontitis in a time- and dose-dependent manner [87] and by F. nucleatum LPS in a dose-dependent manner [88]. IL-1ra inhibits IL-1b synthesis induced by F. nucleatum LPS [88]. P. intermedia LPS induces IL-6 expression (probably mainly transcriptional activation) in human dental pulp fibroblast cultures time- and dose- dependently [89]. Such an IL-6 overexpression is higher than upon Salmonella LPS stimulation [89]. CD14 co-stimulates IL-6 expression in dental-pulp fibroblasts [89]. LPS upregulates the expression of both substance P (SP) and SP-receptor in DPCs, indirectly inducing expression of proinflammatory cytokines [90]. P. intermedia LPS enhances the production of VEGF in DPCs via an sCD14-dependent pathway [91].

\subsubsection{Fibroblasts}

P. intermedia (ATC 25611) LPS enhances the expression of IL-8 mRNA and its release in human dental pulp fibroblasts with a peak at $12 \mathrm{~h}$ [92].

\subsubsection{Odontoblasts}

P. intermedia LPS induces expression of the receptor for advanced glycation end products (RAGE) in odontoblast-like mouse cells [93]. It is a multiligand receptor propagating dysfunction of cells in several inflammatory disorders. LPS also prompts the translocation of high mobility group box 1 (HMGB1) from nucleus to secretory lysosomes, mediated by RAGE and NF- $\mathrm{kB}$ activation [93]. HMGB1 stimulation leads to increased expression of RAGE by human microvascular endothelial cells, production of cell adhesion molecules (ICAM and VCAM) and secretion of proinflammatory cytokines: TNF $\alpha$ and IL-8 [93].

Aggregatibacter actinomycetemcomitans (ATCC29524) LPS was used in one research on rat clonal dental pulp cells with odontoblastic properties [94]. Ozonated water (O3aq) suppresses calcification and immunologic responses. It also protects against direct damage to the cellular wall [94]. These effects may be achieved by directly inhibiting lipid A by O3aq [94].

\subsubsection{DPSCs}

Pseudomonas aeruginosa LPS has a toxic effect on DPSCs in a dose-dependent manner [95]. Pretreatment with static magnetic field (SMF) attenuates inflammatory response and increases viability of cells. SMF can also enhance the proliferation of DPSCs [95].

\subsection{Non-Specific}

\subsection{1. hDPCs}

Several studies did not provide LPS sources. As mentioned before, LPS causes aggravation of ROS activity in cells. These particles may damage DNA and activate inflammation. LPS stimulation elevates levels of $\gamma$-H2A.X, which is a marker of double strand DNA breaks [96]. This leads to overexpression of transcription factor GATA-4, which stimulates NF- $k B$ pathway by nuclear translocation of p 65 with subsequent expression of IL- $1 \beta$, IL-6 and TNF- $\alpha$ [96]. LPS-stimulated cells show upregulated Lin28 (RNA-binding particle) protein expression, followed by downregulation of let- $7 \mathrm{~b}$, let-7g and miR98, and upregulation 
of let-7a, let-7c, let-7d, let-7e, let-7f and let-7i [97]. Let-7 family is a group of microRNAs regulating cell cycle [98].

LPS also stimulates NLRP6 expression and its knock-down decreases IL-1 $\beta$ production [99]. Lipopolysaccharide also upregulates both C5a and C5aR (parts of the complement system) mRNA especially on the second day post-stimulation [100]. Inflammation also raises MMP3 levels. MMP1 production increases upon TNF- $\alpha$ stimulation, but not LPS stimulus [101].

hDPCs possess systems counteracting excess inflammation, such as Angiogenic factor with G patch and FHA domains 1(AGGF1) [102]. It is upregulated in LPS-treated cells and its knock-down activates NF- $\mathrm{kB}$ via promotion of phosphorylation of $\mathrm{p} 65$ and its transfer to the nucleus [102]. Another similarly functioning compound is GPR173 protein [103]. It is a cognate receptor of a newly discovered hormone, phoenixin-20 [104]. GPR173 is downregulated upon LPS stimulation, leading to induced MMP-2 and MMP-9 expression [103]. However, stimulation with phoenixin-20 reverses this negative effect and decreases expression of TLR4 and MyD88 proteins [103].

Lipopolysaccharides may induce autophagy in hDPCs, e.g., by elevating levels of beclin I and LC3-II and subsequent activation of p38 (MAPK pathway) [105]. Autophagy deactivation is associated with pyroptotic cell death mediated through NLRP3 and Casp1 [106]. Rapamycin — an inductor of autophagy — decreases concentration of pyroptotic mediatorsIL-18 and Casp1, subsequently improving LPS-impaired cells viability [106]. An opposite effect is obtained with 3-methyladenine (3-MA), which mitigates autophagy. The key protein regulating autophagy is NF- $\mathrm{KB}$ [106].

Another way LPS works is by activating transient receptor potential vanilloid 1 (TRPV1) canal. Overexpression of SIRT6 protein, which promotes degradation of TRPV1 via its ubiquitination, reduces expression of cytokines-IL-6, IL-1 $\beta$, and TNF- $\alpha$, deactivates NFKB and lowers DMP1 level [107]. Capsaicin stimulates TRPV1 in SIRT6-overexpressed cells, counteracting anti-inflammatory properties [107].

Some anti-inflammatory compounds were studied in LPS-treated cells. Eckols-6-6 bieckol (EB1) and pholorofucofuroeckol-A (EB5) are derived from brown seaweed marine algae (Eisenia bicyclis). They downregulate VCAM-1 and ICAM-1 expression via inhibition of ERK1/2 phosphorylation [108]. Moreover, EB1 mitigates COX-2 expression. Eckoles promote ALP activity and expression of osteogenic molecules [108]. Specific miR146a/PEG-PEI nanoparticles combined with alginate hydrogel with basic fibroblast growth factor (bFGF) stimulate proliferation and promotion of DMP-1 and DSP protein in LPSstimulated hDPCs [109]. Treatment only with miR146a/PEG-PEI downregulates DMP-1 expression [109]. Saxagliptin (DDP4 inhibitor) reduces oxidative stress, mitochondrial dysfunction, and levels of IL-1 $\beta$, IL- 8 and TNF $\alpha$ [110]. Mineral trioxide aggregate is used in clinical practice as a root repair material. Calcium silicate, compared with MTA, improves cells' viability, proliferation and reduces IL-1 $\beta$ levels [111]. Both Biodentine and MTA promote expression of DSPP, proliferation and adhesion of cells via AKT pathway [112].

NG2+ cells are a subtype of hDPCs [113]. They are stem cells derived from mesenchymal tissue. Upon LPS stimulation, NG2+ cells produce more IL- $1 \beta$ and IL-6 than hDPCs. NG2+ cells also show enhanced proliferation rate, migration ability and odontoblastic differentiation-changes comparable with the control pulp cells [113].

\subsubsection{Fibroblasts}

LPS treatment induces labeling of membrane attack complex on the cell surface [114]. It also triggers increased production of $\mathrm{C} 5 \mathrm{a}-\mathrm{a}$ chemotactic factor, taking part in recruiting inflammatory cells and pulp cells responsible for regeneration [114]. LPS-stimulated fibroblasts have increased mRNA and protein expressions of myocyte-enhancer factor 2 (MEF2C), platelet endothelial cell adhesion molecule-1 (PECAM1) and CXCR4 [115]. PECAM1 expression is positively correlated with B-cell signaling pathways, it also plays a role in angiogenesis [115]. Binding PECAM1 to CXCR4 may intensify inflammation and apoptosis via NF-kB signaling pathway [115]. LPS upregulates NLRP3 inflammasome and 
pro-IL-1 $\beta$ expression via TLR4/MyD88/NF- $\kappa$ B pathway [116]. miR-223 is involved in the maintenance of the ATP+LPS-induced production and secretion of the proinflammatory cytokines IL-1 $\beta$ and IL-18 mediated by the NLRP3/CASP1 pathway, targeting NLRP3 [116].

\subsubsection{Odontoblasts}

In odontoblasts, LPS activates the transcription factor FoxO3a $24 \mathrm{~h}$ after LPS stimulation [117]. It is accompanied by a rise in autophagy markers, thus protecting cells from death at an early stage of inflammation [117]. The dentin-odontoblast complex may protect cells from apoptosis [118]. LPS increases production of extracellular vesicles (EVs), especially the exosomal components, attenuating apoptosis [118].

TRL4 and NOD2 are expressed in odontoblasts layer more abundantly than in other human pulp stroma cells, which can provide significant defense and anti-infection responses of the dental pulp. After stimulation of preodontoblast mouse cells with LPS, levels of TLR4, NOD2 IL-1 $\beta$ and autophagy proteins (LC3II, beclin1) increased. LPS induced autophagy is associated with TRL4 activation [119].

\subsubsection{DPSCs}

LPS inhibits the expression of let-7c-5p in rat dental pulp cells [120]. Let-7c-5p may reduce the production of pro-inflammatory cytokines, restoring the viability of cells by suppressing the nuclear translocation of NF-kB p65. A drop in its expression leads to increased expression of dentin matrix protein 1 (DMP1), higher production of pro-inflammatory cytokines and decreased cellular viability [120]. LPS stimulation also regulates other microRNAs: elevates expression of miR-146a-5p, -92b-5p, -218-5p, -23b-5p, -2110, -27a-5p and $-200 b-3 p$ and decreases in miR-223-3p, -1246 and -494-3p [121]. miR-223-3p may play a role in promoting the angiogenesis of HUVECs [121]. A higher expression of miR-506 and downregulation of Sirtuin 1 (SIRT1) are observed in LPS-induced hDPCs-a finding closely associated with activation of the TLR4-NFkB pathway and expression of pro-inflammatory cytokines: IL-1 $\beta$, IL-6, and TNF-a [122]. Human $\beta$-Defensin 4 (HBD4) exerts anti-inflammatory effects in vitro and promotes the mineralization of DPSC [123].

Inflamed DPSCs do not differentiate properly because of decreased Wnt4 expression [124]. Restoring Wnt4 improves the process, likely via JNK signaling pathway [124] (Table 1).

Table 1. Table summarize type of cells, origin of LPS and effects of LPS stimulation of selected studies.

\begin{tabular}{|c|c|c|c|}
\hline Cells & LPS & Effect in LPS-Stimulated Cells & Author \\
\hline $\begin{array}{l}\text { hDPCs from healthy } \\
\text { molar tooth }\end{array}$ & $\begin{array}{c}\text { E. coli LPS } \\
\text { 0111:B4(L5293) }\end{array}$ & $\begin{array}{l}\text { Higher NLRP6 expression. Knockdown of NLRP6 inhibits IL-1B } \\
\text { expression. }\end{array}$ & [99] \\
\hline $\begin{array}{l}\text { hDPCs from healthy } \\
\text { molar tooth }\end{array}$ & E. coli 055:B5 & Upregulated HMGB1. Increased DPCs mobility. & [14] \\
\hline $\begin{array}{l}\text { hDPCs from healthy } \\
\text { molar tooth }\end{array}$ & E. coli 055:B5 & $\begin{array}{l}\text { SITR6 promotes Ku70 deacetylation in LPS-stimulated cells; } \\
\text { suppresses Bax protein release and apoptosis. }\end{array}$ & [22] \\
\hline $\begin{array}{l}\text { hDPCs from healthy } \\
\text { molar tooth }\end{array}$ & E. coli O111:B4 & $\begin{array}{l}\text { High level/activation of PPAR } \gamma \text { inhibits expression of MMP2, } \\
\text { MMP9, VCAM-1 and ICAM-1 }\end{array}$ & [18] \\
\hline $\begin{array}{l}\text { hDPCs and NG2+ from } \\
\text { healthy premolar tooth }\end{array}$ & unspecified & $\begin{array}{l}\text { Upregulated IL-1 } \beta, \text { IL-6, IL-8, and TNF- } \alpha \text { in hDPCs and NG2+. } \\
\text { The latter show enhanced proliferation, migration, odontoblastic } \\
\text { differentiation. }\end{array}$ & [113] \\
\hline hDPCs & E. coli 0127:B8 & $\begin{array}{l}\text { Augmented AGE-1 protein expression. Silencing AGE-1 } \\
\text { attenuates expression of IL- } 1 \beta, \text { IL- } 6 \text {, TNF- } \alpha \text {; decreases nuclear } \\
\text { translocation of } p 65 \text { from NF- } \mathrm{B} \text { p pathway }\end{array}$ & [19] \\
\hline $\begin{array}{l}\text { hDPCs from healthy } \\
\text { molar tooth }\end{array}$ & E. coli & $\begin{array}{l}\text { Betamethasone reduces expression of IL-1 } \beta, \text { IL- } 6, \text { TNF- } \alpha \text { in LPS } \\
\text { induced cells; upregulates ALP, OCN and DSPP proteins }\end{array}$ & [29] \\
\hline
\end{tabular}


Table 1. Cont.

\begin{tabular}{|c|c|c|c|}
\hline Cells & LPS & Effect in LPS-Stimulated Cells & Author \\
\hline $\begin{array}{l}\text { hDPCs-homogeneous, } \\
\text { spindle-shaped } \\
\text { fibroblasts }\end{array}$ & E. coli & $\begin{array}{c}\text { Elevated TET2 mRNA and protein levels. TET2 knockdown } \\
\text { inhibits LPS-induced inflammatory response in hDPCs by } \\
\text { downregulating MyD88 hydroxymethylation. }\end{array}$ & [7] \\
\hline $\begin{array}{l}\text { hDPCs from American } \\
\text { Tissue Culture } \\
\text { Collection (ATCC, } \\
\text { Manassas, VA, USA) }\end{array}$ & E. coli $055: \mathrm{B} 5$ & $\begin{array}{c}\text { Increased NUTM2A-AS1 levels; lowered expression of let-7c-5p. } \\
\text { High level of HMGB-1 attenuates hDPCs vitality, induces } \\
\text { apoptosis and expression of IL-6 and IL-8. }\end{array}$ & [13] \\
\hline $\begin{array}{l}\text { hDPCs from canine, } \\
\text { premolar and molar } \\
\text { healthy teeth }\end{array}$ & unspecified & $\begin{array}{l}\text { Biodentine and MTA did not decrease level of inflammation } \\
\text { related miR-146a but enhanced dentinogenesis, proliferation and } \\
\text { adhesion features of cells. }\end{array}$ & [112] \\
\hline $\begin{array}{l}\text { hDPCs from healthy } \\
\text { permanent teeth }\end{array}$ & P. gingivalis & $\begin{array}{c}\text { ECG and EGCG reduce mRNA expression and IL-1 } \beta, \text { IL- } 6 \text {, } \\
\text { TNF- } \alpha \text { secretion by interfering with NF- } \mathrm{B} \text { pathway and } \\
\text { reducing p } 65 \text { levels. }\end{array}$ & [79] \\
\hline $\begin{array}{l}\text { hDPCs_-dental-pulp } \\
\text { fibroblasts }\end{array}$ & P. intermedia & $\begin{array}{l}\text { Upregulated mRNA expression for Substance P and its receptor. } \\
\text { Substance P enhances LPS-induced expression of IL- } 1 \alpha \text { and } \\
\text { COX-2; increases LPS-induced NF-KB binding activity. }\end{array}$ & [90] \\
\hline $\begin{array}{l}\text { hDPCs-dental-pulp } \\
\text { fibroblasts }\end{array}$ & $\begin{array}{l}\text { P. intermedia, } \\
\text { Salmonella abortusequi, } \\
\text { E. coli }\end{array}$ & $\begin{array}{l}\text { CD14 is costimulatory in IL-6 expression in dental-pulp } \\
\text { fibroblasts. Higher IL-6 activity in P. intermedia culture than in } \\
\text { Salmonella. }\end{array}$ & [89] \\
\hline $\begin{array}{l}\text { hDPCs from healthy } \\
\text { molar tooth }\end{array}$ & P. gingivalis & $\begin{array}{c}\text { Increased levels of IFN- } \beta 1 \text { (after 3h), NLRP6, CASP1, CASP4 } \\
\text { (after 6h). Blocking IFNAR1 lowers expression of those particles. } \\
\text { Higher expression of IL-1 } \beta \text {. }\end{array}$ & [73] \\
\hline $\begin{array}{l}\text { hDPCs from healthy } \\
\text { molar tooth }\end{array}$ & E. coli $0111: \mathrm{B} 4$ & $\begin{array}{c}\text { Decreased ATG-5, Beclin-I and LC3-I/II (autophagy), HO-1 and } \\
\text { PGC-1 } \alpha \text { (mitochondria). Schisandrin C treatment recovered } \\
\text { expression of all mentioned proteins. }\end{array}$ & [23] \\
\hline $\begin{array}{l}\text { hDPCs from healthy } \\
\text { molar tooth }\end{array}$ & unspecified & $\begin{array}{c}\text { Inhibited GPR173 mRNA and protein expression -maximal effect } \\
\text { at 24h. Phoenixin20 inhibits expression of MMP2 and MMP9; } \\
\text { suppresses TLR4 and MyD88. The effect of phoenixin20 depends } \\
\text { on GPR173. }\end{array}$ & [103] \\
\hline
\end{tabular}

hDPCs immortalized by

transfection with a

human telomerase

transcriptase gene

(HPD-hTERTs)

hDPCs immortalized by

transfection with a

human telomerase

transcriptase gene

(HPD-hTERTs)

hDPCs and from healthy premolar tooth

E. coli 0111:B4

Higher IL-1 $\beta$, IL-6 expression. Induced Wnt5a, Runx2, and ALP (markers of dentinogenesis). Box-5 (Wnt5a antagonist) treatment mitigates expression of Runx2 and ALP.
[40]

LPS with TNF- $\alpha$ upregulates VEGF and SIRT1 with subsequent upregulation of MMP-2 and MMP-9. Pathway that leads to this activation involves PI3K, p38, ERK, JNK and NF- $\mathrm{BB}$.
Upregulated AGGF1 protein inhibits phosphorylation of NF- $\mathrm{KB}$ and its transfer into the nucleus.

Upregulated expression of GATA4, $\gamma$-H2A.X and p65. Higher

hDPCs from healthy molar tooth

unspecified ROS levels cause double-strand breaks. Subsequently, $\gamma$-H2A.X upregulates GATA4 and intensifies p65 translocation into nucleus.

Elevated IL-1 $\beta$, IL-6, TNF- $\alpha$ levels.

hDPCs unspecified

EB1 and EB5 lower ICAM-1 and VCAM-1 expression, inhibiting ERK and JNK kinases and blocking translocation of NF-KB into nucleus. EB1 mitigates COX-2 expression. 
Table 1. Cont.

\begin{tabular}{|c|c|c|c|}
\hline Cells & LPS & Effect in LPS-Stimulated Cells & Author \\
\hline $\begin{array}{l}\text { hDPCs from healthy } \\
\text { molar tooth }\end{array}$ & E. coli $0111: \mathrm{B} 4$ & $\begin{array}{l}\text { Overexpressed miR-21-5p decreases NF-kB p65 phosphorylation, } \\
\text { expression of IL-6, interfering with TRAF6 mRNA, part of TLR4 } \\
\text { transduction complex. }\end{array}$ & [15] \\
\hline $\begin{array}{l}\text { hDPCs from healthy } \\
\text { molar tooth }\end{array}$ & E. coli & $\begin{array}{l}\text { EGCG and ECG reduce IL-6, IL-8, VCAM-1 and ICAM-1 protein } \\
\text { expression. }\end{array}$ & {$[36]$} \\
\hline $\begin{array}{l}\text { hDPCs from healthy } \\
\text { tooth }\end{array}$ & E. coli & $\begin{array}{l}\text { EGCG and ECG reduce LPS-mediated VEGF production. } \\
\text { Catechins attenuated COX-2 expression. }\end{array}$ & [37] \\
\hline $\begin{array}{l}\text { hDPCs from healthy } \\
\text { tooth }\end{array}$ & $\begin{array}{l}\text { P. gingivalis AEI2, } P \text {. } \\
\text { endodontalis AE51, and } \\
\text { F. nucleatum }\end{array}$ & $\begin{array}{l}\text { E. coli LPS inhibits cell protein production more potently than } \\
\text { LPS from other types. Unlike others, the E. coli LPS induces DNA } \\
\text { production by dental pulp cells. }\end{array}$ & [86] \\
\hline $\begin{array}{l}\text { hDPCs from healthy } \\
\text { premolar tooth }\end{array}$ & P. gingivalis & $\begin{array}{l}\text { Downregulation of mRNA for DNMT3B and protein level of } \\
\text { DNMT1. Inhibition of those protein results in upregulation of } \\
\text { miR-146a-5p. }\end{array}$ & [70] \\
\hline $\begin{array}{l}\text { hDPCs from healthy } \\
\text { tooth }\end{array}$ & P. intermedia & Enhanced VEGF production & [91] \\
\hline $\begin{array}{l}\text { hDPCs from healthy } \\
\text { tooth }\end{array}$ & F. nucleatum & Both LPS and IL-1ra reduce IL-1 $\beta$ synthesis. & [88] \\
\hline $\begin{array}{l}\text { hDPCs from healthy } \\
\text { premolar tooth }\end{array}$ & E. coli & $\begin{array}{l}\text { Fluocinolone acetonide upregulates DSPP, RUNX2, inhibiting } \\
\text { phosphorylated NF- } \mathrm{B} \text { p } 65 \text { and activating AP-1. FA may restore } \\
\text { expression of ALP, RUNX2 and DSPP. }\end{array}$ & [28] \\
\hline $\begin{array}{l}\text { hDPCs from healthy } \\
\text { premolar or molar teeth }\end{array}$ & unspecified & $\begin{array}{c}\text { Overexpression of Lin28 RNA binding protein lowers let-7b, } \\
\text { let-7g and miR98 levels. }\end{array}$ & [97] \\
\hline
\end{tabular}

Primary human dental

pulp cells were

purchased from

American

E. coli and P. gingivalis

Tenegliptin reduces production of 4-HNE from lipid peroxidation as the result of ROS activity in LPS stimulated cells. In addition, suppresses TLR4 mRNA and protein levels after LPS treatment.

Type Culture Collection (ATCC).

\begin{tabular}{|c|c|c|c|}
\hline $\begin{array}{l}\text { hDPCs from healthy } \\
\text { molar tooth }\end{array}$ & unspecified & Upregulated C5a and C5aR mRNA and protein expression & [100] \\
\hline $\begin{array}{l}\text { hDPCs from healthy } \\
\text { premolar tooth }\end{array}$ & E. coli $0111: \mathrm{B} 4$ & $\begin{array}{c}\text { Upregulated lncMEG3; its knock-down inhibits the secretion of } \\
\text { IL-1 } \beta, \text { IL-6, TNF- } \alpha \text { and promotes odontogenic differentiation } \\
\text { through Wnt/ } \beta \text {-catenin pathway. }\end{array}$ & [12] \\
\hline $\begin{array}{l}\text { hDPCs from healthy } \\
\text { molar tooth }\end{array}$ & unspecified & $\begin{array}{l}\text { Specific miR-146a/PEG-PEI nanoparticles combined with } \\
\text { alginate hydrogel with basic fibroblast growth factor stimulate } \\
\text { cell proliferation and expression of DMP-1 and DSP protein. }\end{array}$ & [109] \\
\hline $\begin{array}{l}\text { hDPCs from healthy } \\
\text { molar tooth }\end{array}$ & E. coli $0111: \mathrm{B} 4$ & $\begin{array}{l}\text { Higher levels of OCT4B1 leading to decreased percentage of } \\
\text { apoptotic cells in viability tests. }\end{array}$ & [9] \\
\hline $\begin{array}{l}\text { hDPCs from healthy } \\
\text { molar tooth }\end{array}$ & E. coli & $\begin{array}{l}\text { Induced expression of sclerostin; subsequent increase of } \\
\text { proinflammatory cytokines through NF-kB pathway. Sclerostin } \\
\text { induces expression of VCAM-1 and ICAM-1 and inhibits } \\
\text { odontoblastic differentiation. LPS upregulates VEGF, VEGFR and } \\
\text { PlGF expression; effect aggravated by sclerostin. }\end{array}$ & [54] \\
\hline
\end{tabular}

hDPCs immortalized by

transfection with a human telomerase transcriptase gene 
Table 1. Cont.

\begin{tabular}{|c|c|c|c|}
\hline Cells & LPS & Effect in LPS-Stimulated Cells & Author \\
\hline $\begin{array}{l}\text { hDPCs from healthy } \\
\text { molar tooth? }\end{array}$ & E. coli $0111: \mathrm{B} 4$ & $\begin{array}{c}\text { Davallialactone eliminates ROS from LPS-induced cells. } \\
\text { Decreased expression of ICAM-1, VCAM-1, MMP-2, MMP-9, } \\
\text { iNOS and COX-2, caused by inhibiting inflammation at the } \\
\text { ERK1/2 and NF-kB stages. }\end{array}$ & [24] \\
\hline $\begin{array}{l}\text { hDPCs from healthy } \\
\text { molar tooth }\end{array}$ & E. coli 0111:B4 & $\begin{array}{l}\text { Terrein reduces ICAM-1, VCAM-1 levels by blocking Akt-1 action } \\
\text { and suppressing NF- } \mathrm{kB} \text { activation. }\end{array}$ & {$[34]$} \\
\hline $\begin{array}{l}\text { hDPCs from healthy } \\
\text { molar tooth }\end{array}$ & E. coli & $\begin{array}{l}\text { Upregulated Oct- } 4 \mathrm{~B} 1 \text { and Oct- } 4 \mathrm{~B} \text { mRNA levels. Oct- } 4 \mathrm{~B} 1 \\
\text { knock-down downregulates Oct- } 4 \mathrm{~B} \text { and increases number of } \\
\text { apoptotic cells. Absence of Oct- } 4 \mathrm{~B} 1 \text { change expression pattern of } \\
38 \text { microRNA. }\end{array}$ & [8] \\
\hline $\begin{array}{l}\text { hDPCs from healthy } \\
\text { molar tooth }\end{array}$ & P. gingivalis & $\begin{array}{l}\text { GV1001 peptide inhibits LPS-induced IL-6, TNF- } \alpha \text { expression. } \\
\text { Effect mediated by reduced phosphorylation of ERK and p38 } \\
\text { MAP kinases. }\end{array}$ & [78] \\
\hline $\begin{array}{l}\text { hDPCs from maxillary } \\
\text { supernumerary incisors } \\
\text { and molar teeth }\end{array}$ & P. gingivalis & $\begin{array}{l}\text { PRFe attenuate IL-1 } \beta \text {, IL-6, IL-8, VCAM-1, ICAM-1 expression; } \\
\text { enhances dentin sialophosphoprotein, dentin matrix acidic } \\
\text { phosphoprotein } 1 \text { expression and increases ALP activity }\end{array}$ & [82] \\
\hline $\begin{array}{l}\text { hDPCs from healthy } \\
\text { molar tooth }\end{array}$ & E. coli 0111:B4 & $\begin{array}{c}\text { Decreased PPAR } \gamma \text { levels, ERK } 1 / 2 \text { activities and NF- } \mathrm{KB} \\
\text { translocation. Rosiglitazone decreases proinflammatory } \\
\text { stimulation. Activity of PPAR } \gamma \text { mediated by removal of ROS } \\
\text { formation. }\end{array}$ & [17] \\
\hline $\begin{array}{l}\text { hDPCs immortalized by } \\
\text { transfection with a } \\
\text { human telomerase } \\
\text { transcriptase gene } \\
\text { (HPD-hTERTs) }\end{array}$ & P. gingivalis & $\begin{array}{c}\text { Glutamine reduces iNOS and COX-2 expression, inhibits IL-1 } \beta \text {, } \\
\text { IL-8, TNF- } \alpha \text { production and attenuates MAP kinases } \\
\text { phosphorylation, NF- } \mathrm{kB}-\mathrm{p} 65 \text { nuclear translocation; induces } \\
\text { MKP-1 expression. }\end{array}$ & [80] \\
\hline $\begin{array}{l}\text { hDPCs from healthy } \\
\text { deciduous tooth }\end{array}$ & unspecified & $\begin{array}{l}\text { TNF- } \alpha \text { and LPS stimulation increases MMP-1 and MMP-3 mRNA } \\
\text { levels, but only MMP-3 protein. }\end{array}$ & [101] \\
\hline $\begin{array}{l}\text { hDPCs from healthy } \\
\text { deciduous tooth }\end{array}$ & unspecified & $\begin{array}{c}\text { Simvastatin reduces LPS-stimulated IL-1 } \beta, \text { IL- } 6 \text {, VCAM-1, } \\
\text { ICAM-1 production, attenuating phosphorylation and } \\
\text { translocation of } \mathrm{p}-65 \text { and I- } \mathrm{k} \text { B. }\end{array}$ & {$[30]$} \\
\hline $\begin{array}{l}\text { hDPCs from healthy } \\
\text { molar tooth }\end{array}$ & unspecified & $\begin{array}{l}\text { Induced expression of beclin-1 and LC3II (autophagy) via MAP } \\
\text { kinases phosphorylation and translocation of NF- KB into the } \\
\text { nucleus. }\end{array}$ & [105] \\
\hline $\begin{array}{l}\text { hDPCs from healthy } \\
\text { premolar or molar teeth }\end{array}$ & unspecified & $\begin{array}{l}\text { In odontogenic induction medium: increased ALP activity, } \\
\text { DSPP-1 and DMP-1 expression. Enhanced NF- } \mathrm{B} \text { B translocation } \\
\text { into nucleus. }\end{array}$ & [39] \\
\hline $\begin{array}{l}\text { hDPCs from healthy } \\
\text { premolar or molar teeth }\end{array}$ & unspecified & $\begin{array}{l}\text { SIRT6 overexpression downregulates IL-1 } \beta, \text { IL- } 6, \text { TNF- } \alpha \text { and } \\
\text { inhibits NF-kB pathway; reduces expression of TRPV1, whose } \\
\text { activation by capsaicin upregulates expression of } \\
\text { proinflammatory cytokines. }\end{array}$ & [107] \\
\hline $\begin{array}{l}\text { hDPCs from healthy } \\
\text { permanent teeth }\end{array}$ & P. endodontalis & $\begin{array}{l}\text { Increased IL-1 } \beta \text { mRNA and protein level in a dose-dependent } \\
\text { manner. }\end{array}$ & [87] \\
\hline $\begin{array}{l}\text { hDPCs from human } \\
\text { supernumerary teeth }\end{array}$ & E. coli & $\begin{array}{l}\text { Bromelain reduces IL-1 } \beta, \text { IL-6, IL-8, VCAM-1 and ICAM-1 } \\
\text { expression by inhibiting phosphorylation of p65 protein, ERK } \\
\text { and p38 kinases; increases ALP activity. }\end{array}$ & {$[33]$} \\
\hline $\begin{array}{l}\text { hDPCs from human } \\
\text { supernumerary teeth }\end{array}$ & unspecified & $\begin{array}{l}\text { Promotion of pyroptotic cell death, with increased levels of IL } 1 \beta \text {, } \\
\text { IL } 18 \text { and caspase } 1 . \text { Promotion of autophagy inhibits pyroptotic } \\
\text { cell death. }\end{array}$ & [106] \\
\hline $\begin{array}{l}\text { hDPCs from healthy } \\
\text { molar tooth }\end{array}$ & E. coli 0111:B4 & $\begin{array}{l}\text { The antioxidant effect of sole N-acetylcysteine (NAC) not evident. } \\
\text { In combination with Biodentine or MTA, improved LPS-induced } \\
\text { hDPCs survival at } 24 \mathrm{~h} \text {. NAC+MTA promoted mineralization. }\end{array}$ & [27] \\
\hline
\end{tabular}


Table 1. Cont.

\begin{tabular}{cccc}
\hline Cells & LPS & Effect in LPS-Stimulated Cells & Author \\
\hline $\begin{array}{c}\text { hDPCs from healthy } \\
\text { molar tooth }\end{array}$ & P. gingivalis & $\begin{array}{c}\text { Elevated cell apoptosis (higher caspase 3 activity) inhibited cell } \\
\text { proliferation and survival, lower SIRT6 expression. SIRT6 has } \\
\text { anti-apoptotic effect via regulating Ku70 protein deacetylation. }\end{array}$ & [74] \\
$\begin{array}{c}\text { hDPCs from healthy } \\
\text { premolar and molar } \\
\text { teeth }\end{array}$ & E. coli & $\begin{array}{c}\text { Upregulated secretion of IL-6 and IL-8. 5-Aza-CdR can promote } \\
\text { LPS-induced inflammation by upregulating proinflammatory } \\
\text { cytokines expression and activating NF- } \mathrm{kB} \text { and MAPK signaling } \\
\text { pathways by decreasing the methylation level of TRAF6 }\end{array}$ & $\begin{array}{c}\text { [11] } \\
\text { promoter. }\end{array}$ \\
\hline
\end{tabular}

Primary human dental
pulp cells were
purchased from $\quad$ unspecified
American
(ATCC).

\begin{tabular}{|c|c|c|c|}
\hline $\begin{array}{l}\text { hDPCs from healthy } \\
\text { premolar tooth }\end{array}$ & unspecified & $\begin{array}{l}\text { MTA stimulates IL-1 } \beta \text { expression and apoptosis. CS cement } \\
\text { enhances cellular proliferation. }\end{array}$ & [111] \\
\hline $\begin{array}{l}\text { hDPCs from healthy } \\
\text { premolar and molar } \\
\text { teeth }\end{array}$ & E. coli & $\begin{array}{c}\text { Decreased expression of methyltransferase DNMT1, leading to } \\
\text { increased cytokine secretion and activating NF- } \mathrm{kB} \text { and MAPK } \\
\text { signaling. Silencing DNMT1 contributes to downregulating } \\
\text { methylation levels at the promoters of IL-6 and TRAF6. }\end{array}$ & [10] \\
\hline $\begin{array}{l}\text { hDPCs from healthy } \\
\text { premolar and molar } \\
\text { teeth }\end{array}$ & E. coli & $\begin{array}{l}\text { Nell-1 may attenuate LPS-induced inflammation acting via p38 } \\
\text { and ERK MAPK, but not JNK MAPK signaling pathway. }\end{array}$ & [31] \\
\hline $\begin{array}{l}\text { hDPCs from healthy } \\
\text { premolar and molar } \\
\text { teeth }\end{array}$ & unspecified & $\begin{array}{l}\text { Upregulated expression of m6A and METTL3. METTL3 depletion } \\
\text { decreased the accumulation of inflammatory cytokines and } \\
\text { suppressed the NF- } \mathrm{B} \text { B and MAPK signaling pathways. METTL3 } \\
\text { modulated the alternative splicing of MyD88. }\end{array}$ & [72] \\
\hline $\begin{array}{l}\text { hDPCs from healthy } \\
\text { molar teeth }\end{array}$ & E. coli 0111:B4 & $\begin{array}{l}\text { HIF1a suppressed IL-6 expression via SOCS3-dependent } \\
\text { downregulation of CEBPb. }\end{array}$ & {$[21]$} \\
\hline $\begin{array}{l}\text { hDPCs from healthy } \\
\text { molar teeth }\end{array}$ & E. coli $0111: \mathrm{B} 4$ & $\begin{array}{l}\text { HIF1a promotes pro-inflammatory mediator synthesis via NF- } \mathrm{kB} \\
\text { signaling-increased levels of IL1b and TNF } \alpha \text {. HIF- } 1 \alpha \text { also } \\
\text { upregulates phosphorylation of NF- } \mathrm{B} \text { B p65 and activation of } \\
\text { NF- } \mathrm{k} \text { B signaling. LPS stimulation induced HIF1a expression. }\end{array}$ & [20] \\
\hline $\begin{array}{l}\text { hDPCs from healthy } \\
\text { deciduous tooth }\end{array}$ & E. coli & $\begin{array}{l}\text { Acemannan from Aloe vera, induces proliferation, differentiation, } \\
\text { growth factor and extracellular matrix components synthesis in } \\
\text { LPS stimulated cells. }\end{array}$ & [38] \\
\hline Human pulp fibroblasts & unspecified & $\begin{array}{l}\text { Induced membrane attack complex labeling on the cell surface. } \\
\text { Increased C5a levels in LPS-treated fibroblasts. }\end{array}$ & [114] \\
\hline Human pulp fibroblasts & E. coli 055B5 & $\begin{array}{l}\text { Enhanced IL6 and CH3SH production. LPS doesn't stimulate } \\
\text { IL-1 } \beta \text { and TNF } \beta \text { production }\end{array}$ & [42] \\
\hline Human pulp fibroblasts & E. coli & $\begin{array}{c}\text { Upregulated production of CCL2, IL- } 8 \text { and Il- } 6 \text {. Less pronounced } \\
\text { elevation in IL-4, GCFS, GM-CSF and CCL5, followed by IL-1 } \beta \text {, } \\
\text { IL-10, IL12p70, IL-17A, TNF- } \alpha \text { and INF- } \lambda \text {. Most cytokines } \\
\text { stimulated during the first } 6 \mathrm{~h} .\end{array}$ & [41] \\
\hline Human pulp fibroblasts & P. gingivalis W83 & IL-8 detectable after LPS stimulation. & [83] \\
\hline Human pulp fibroblasts & E. coli O111:B4 & $\begin{array}{l}\text { Induced release of IL-1 } \beta \text {, no effect on NLRP3/caspase-1 } \\
\text { inflammasome. ATP + LPS stimulate the pyrogenic P2X7 } \\
\text { ATP-gated ion channel, activating the NLRP3/caspase- } 1 \text { pathway } \\
\text { and inducing the maturation and release of IL-1 } \beta \text {. }\end{array}$ & {$[43]$} \\
\hline Human pulp fibroblasts & E. coli & $\begin{array}{c}\text { COX-2, but not COX-1 was induced by E. coli LPS after } \\
\text { stimulation for } 3 \text { h. Exogenous melatonin suppresses COX-2 and } \\
\text { IL-1 } \beta \text {. }\end{array}$ & {$[45]$} \\
\hline
\end{tabular}


Table 1. Cont.

\begin{tabular}{cccc}
\hline Cells & LPS & Effect in LPS-Stimulated Cells & Author \\
\hline Human pulp fibroblasts & unspecified & $\begin{array}{c}\text { Increased mRNA and protein expression of MEF2C, PECAM1 } \\
\text { and CXCR4. }\end{array}$ \\
\hline Human pulp fibroblasts & $\begin{array}{c}\text { P. intermedia ATCC } \\
\text { 25611 }\end{array}$ & $\begin{array}{c}\text { P. intermedia LPS expressed IL-8 mRNA and released IL-8 in } \\
\text { human dental pulp fibroblast cultures, expression peaked after 12 h. }\end{array}$ \\
\hline $\begin{array}{c}\text { [92] } \\
\text { Human pulp fibroblasts }\end{array}$ & E. coli & $\begin{array}{c}\text { Increased expression of miR-146a in dental pulp cells (also in } \\
\text { gingiva and periodontal ligament fibroblasts). Decreased } \\
\text { expression of miR-155 in gingival fibroblasts. }\end{array}$ \\
\hline $\begin{array}{c}\text { Human pulp fibroblasts } \\
\text { from permanent and } \\
\text { deciduous teeth }\end{array}$ & P. gingivalis & $\begin{array}{c}\text { Increased CCL3 production in cells from both permanent and } \\
\text { deciduous teeth. Pulp fibroblasts from deciduous teeth had } \\
\text { elevated production of CXCL12. }\end{array}$ \\
\hline $\begin{array}{c}\text { Human pulp fibroblasts } \\
\text { [48] }\end{array}$ & E. coli 055:B5, L2880 & $\begin{array}{c}\text { Downregulated miR-21 and upregulated KBTBD7. Berberine } \\
\text { reduced expressions of IL-1 } \beta, \text { IL-6 and TNF- } \alpha, \text { as well as } \\
\text { enhanced cell proliferation and miR-21 expression. }\end{array}$
\end{tabular}

ATP + LPS reduced miR-223 expression in human dental pulp Human pulp fibroblasts $\quad$ unspecified cells. miR-223 negatively regulated production and secretion of IL-1 $\beta$ and IL-18, acting via the NLRP3/CASP1 inflammasome pathway by targeting NLRP3.

LPS + ATP increases IL-1 $\beta$ secretion via NLRP3 inflammasome activating caspase- 1 . The TLR4/MyD88/NF- $\mathrm{kB}$ mediates

Human pulp fibroblasts from premolars

E. coli 0111:B4

up-regulation of NLRP3 and pro-IL-1 $\beta$ genes expression. ATP promotes ROS production which serves as the second signal for the activation of NLRP3 inflammasome.

\begin{tabular}{cc}
\hline $\begin{array}{c}\text { hDPSCs from healthy } \\
\text { molar tooth }\end{array}$ & E. coli \\
\hline $\begin{array}{c}\text { Adult human dental } \\
\text { pulp stem cells }\end{array}$ & unspecified \\
\hline $\begin{array}{c}\text { Adult human dental } \\
\text { pulp stem cells from first } \\
\text { premolars }\end{array}$ & E. coli
\end{tabular}
premolars

coli

DPSCs/NF-PLLA scaffold constructs with simvastatin reversed LPS induced TNF- $\alpha$, IL-1 $\beta$ and MMP-9 mRNA expression on day 28.

$20 \%$ HPL stimulates angiogenesis by increasing levels of pro-angiogenic factors' $\mathrm{mRNA}$ and protein

Induced expression of IL-6, IL-8, tPA and TAC1 levels. Levels of

IL- $1 \alpha$ were increasing proportionally to LPS concentrations.

TNF $\alpha$ showed increased expression with no changes at gene expression level. This could be attributed to initiation of inflammation via TLR4 and TLR2. The viability was reduced in LPS treated cells.

LPS and TNF activated the NF-kB signaling pathway. Stimulation by the latter lasted longer. TNF induced the phosphorylation and degradation of $I \kappa B \alpha$ more potently than LPS. LPS did not induce phosphorylation of p65 transactivation domain, while TNF only weakly stimulated $\mathrm{p} 65$ phosphorylation. human dental pulp stem mandibular molars cells from third
P. gingivalis, P. endodontalis
E. coli 0111:B4L2880
4-MU may facilitate cell differentiation by downregulating the expression of inflammatory cytokines. CD44 expression was downregulated upon 4-MU treatment or with LPS. CD44 plays a primary role in HA-induced cytokine release via the formation of the LMW HA-TLR4-CD44 complex. 4-MU could accelerate the LPS-induced migration of hDPSCs.
Altered content of dental pulp cells-derived small extracellular vesicles (sEVs). sEVs carry biologically active molecules from parental cells, which can mediate intercellular communication, induce MSC differentiation, and ultimately promote the healing. 
Table 1. Cont.

\begin{tabular}{|c|c|c|c|}
\hline Cells & LPS & Effect in LPS-Stimulated Cells & Author \\
\hline $\begin{array}{l}\text { human dental pulp stem } \\
\text { cells from third molars }\end{array}$ & E. coli 0111:B4 & $\begin{array}{l}\text { More pronounced SA-b-gal-positive signal (a maker of } \\
\text { senescence), likely resulting from TLR4/MyD88-NF-jB-p53/p21 } \\
\text { signaling pathway activation. Knockdown of p65 reversed the } \\
\text { senescence of enhanced proliferation and the increased the total } \\
\text { number of DPSCs with more organized F-actin. }\end{array}$ & {$[65]$} \\
\hline $\begin{array}{l}\text { human dental pulp stem } \\
\text { cells from third molars }\end{array}$ & E. coli 0111:B4 & $\begin{array}{c}\text { LPS binding with TLR4 generates ROS. The DDR and p16INK4A } \\
\text { pathways might be the main mediators of DPSC LPS-induced } \\
\text { senescence. ROS production may promote DDR and p16INK4A } \\
\text { expression and then cell cycle arrest. }\end{array}$ & {$[64]$} \\
\hline $\begin{array}{l}\text { human dental pulp stem } \\
\text { cells from premolars or } \\
\text { third molars }\end{array}$ & E. coli 055:B5 & $\begin{array}{l}\text { SDF-1a secretion largely suppressed, increased production of } \\
\text { CXCR4. }\end{array}$ & {$[63]$} \\
\hline $\begin{array}{l}\text { human dental pulp stem } \\
\text { cells from third molars }\end{array}$ & Ultrapure E. coli & $\begin{array}{c}\text { LPS can enhance Wnt5a expression preincubation with TLR4 } \\
\text { neutralizing antibodies reduced LPS-induction Wnt5a expression } \\
\text { (mainly activated through the MyD88-dependent pathway). } \\
\text { NF-kB activation and PI3K/AKT signal pathways regulate Wnt5a } \\
\text { expression. }\end{array}$ & {$[58]$} \\
\hline $\begin{array}{l}\text { human dental pulp stem } \\
\text { cells }\end{array}$ & Ultrapure E. coli & $\begin{array}{l}\text { Induced odontogenic differentiation by increasing ALP, OCN, } \\
\text { DMP1 and DSPP expression and mineralized nodules formation. } \\
\text { TLR4 expression maximal after } 7 \text { days. Inhibiting or blocking } \\
\text { TLR4 decreased the LPS-mediated expression of mineralized } \\
\text { tissue markers and nodule formation. NF-kB signaling activated } \\
\text { by LPS in a time-dependent manner, but not involved in cellular } \\
\text { differentiation. Activation of p38 and ERK MAPK, not JNK } \\
\text { MAPK signaling pathways contribute to LPS-induced } \\
\text { differentiation of hDPSCs. }\end{array}$ & {$[61]$} \\
\hline
\end{tabular}

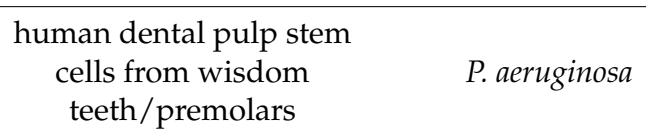

Dose-dependent toxic effect. (SMF) stimulation inhibits inflammatory response, can enhance proliferation.

Exosomes from LPS-stimulated hDPSCs exert a stronger pro-angiogenic effect on HUVECs than normal

human dental pulp stem

unspecified cells from third molars

hDPSCs-LPS-dose dependently. Expression of 7 microRNAs were increased (miR-146a-5p, miR-92b-5p, miR-218-5p, miR-23b-5p, miR-2110, miR-27a-5p, and miR-200b-3p) and 3 decreased (miR-223-3p, miR-1246 and miR-494-3p). Five of them play important roles in inflammation and HUVEC function and angiogenesis (miR-223-3p being the strongest candidate).

High expression of $\gamma$-H2A.X. marker of DSB. The mRNA and protein expression levels of Ku70 and Xrcc4 involved in NHEJ, and Rad51 in HR, significantly increased in DPSCs. Ku70

knockdown reduces the expression of XRCC4 and promotes apoptosis of DPSCs during inflammation, thereby Ku70 serves as a link between DNA damage and apoptosis.

Upregulated CD146 expression levels. Partially blocked human dental pulp stem cells from third molars

E. coli expression of the NF- $\mathrm{KB}$ subunit p65 leading to reduced TNF- $\alpha$ production by macrophages. The innate immune response dependent on the TNF- $\alpha /$ IDO axis.

EGCG exerted an anti-inflammatory effect on hDPSCs without

human dental pulp stem cells from third molars

E. coli affecting cell proliferation or differentiation. EGCG inhibits hypoxia-induced apoptosis. 
Table 1. Cont.

\begin{tabular}{ccc}
\hline Cells & LPS & Effect in LPS-Stimulated Cells \\
\hline rat dental pulp stem cells & E. coli 055:B5 & $\begin{array}{c}\text { LPS at low concentrations upregulated mRNA expression of } \\
\text { mineralization-related genes (OCN, DSPP, ALP and BSP) in } \\
\text { JDPSCs and ADPSCs, LPS effects declined with age. Enhanced } \\
\text { proliferation by increasing TLR4 expression and through } \\
\text { PI3K/Akt signaling. }\end{array}$ \\
\hline $\begin{array}{c}\text { [59] } \\
\text { cells from third molars }\end{array}$ & unspecified & $\begin{array}{c}\text { VEGFA promoted the migration of hDPSCs in a } \\
\text { concentration-dependent manner. VEGFA/VEGFR2 axis } \\
\text { interacted with the FAK/PI3K/Akt and p38 MAPK signaling } \\
\text { pathwas in mediating hDPSCs migration. }\end{array}$
\end{tabular}

\section{human dental pulp stem}

cells from premolars

(DPSCs) and stem cells from

human exfoliated deciduous teeth (SHED)
E. coli

Betamethasone blocks NF- $\mathrm{KB}$ activation and exhibits an osteo-/odonto-inductive effect on DPSCs and SHED. It also displays an osteoclast effect on SHED, not on the DPSCs.

The expression of miR-506 was high while that of SIRT1 was low, which was associated with pro-inflammatory cytokines upregulation and activation of the TLR4-NFkB pathway.

Decreased cell survival and more frequent necrosis. Reduced

human dental pulp stem cells from third molars unspecified COL1A1 expression after $21 \mathrm{~d}$. Promoted production of IL-6 in the late phase.

human dental pulp stem cells from third molars unspecified Simvastatin promoted cell proliferation, cell cycling and apoptosis in LPS-induced DPSCs. Expression of cytokines and VEGF (via MAPK signaling blockade) was inhibited.

Inhibited expression of let-7c-5p both in vivo and in vitro. The overexpression of let-7c-5p suppressed the production of pro-inflammatory cytokines, restoring viability; also inhibited the LPS-induced activation of NF-kB signaling by inhibiting the phosphorylation of IKBa and IKKb and increasing total IKBa expression, hence suppressing the nuclear translocation of NF-kB p65. let-7c-5p action depends on the inhibition of DMP1 function.

Induced expression of let-7c-5p could suppress inflammation and restored the osteogenic differentiation potential of inflamed DPSCs. The effect depended on the repression on HMGA2 function by let-7c-5p, leading to inhibiting PI3K/Akt pathway.

Human $\beta$-Defensin 4 (HBD4) shows anti-inflammatory activity

human dental pulp stem cells

unspecified in vitro, by reduction of IL- $1 \alpha$, IL-1 $\beta$, IL- 6 and TNF- $\alpha$ expression and promotes mineralizing cell phenotype differentiation in DPSC. Similar effects are noted in vivo.

human dental pulp stem cells-normal pulp derived from the mandibular third molar and inflamed pulps derived from pulps of patients with irreversible pulpitis

odontoblast-like cells (MDPC-23), undifferentiated dental pulp cells (OD-21), macrophages, and gingival fibroblasts and human embryonic kidney cells (293T, ATCC)
Decreased Wnt4 expression, impairing the odontogenic differentiation of DPSCs. Restoration of Wnt4 was able to unspecified rehabilitate the impaired odontogenic differentiation potential. Wnt4 may function through its effect on JNK signaling pathways. 
Table 1. Cont.

\begin{tabular}{|c|c|c|c|}
\hline Cells & LPS & Effect in LPS-Stimulated Cells & Author \\
\hline $\begin{array}{l}\text { odontoblast-like cells } \\
\quad \text { (MDPC-23) }\end{array}$ & E. coli $\mathrm{k}-235$ strain & $\begin{array}{l}\text { Odontoblast-like cells produce secretory leukocyte protease } \\
\text { inhibitor (SLPI) in response to LPS, inhibiting the activation of } \\
\text { NF-kB. }\end{array}$ & {$[51]$} \\
\hline $\begin{array}{l}\text { Human odontoblasts } \\
\text { from third molars }\end{array}$ & E. coli 055:B5 & Upregulated IL-8 mRNA and protein levels. & {$[50]$} \\
\hline $\begin{array}{l}\text { self-established } \\
\text { pre-odontoblastic cell } \\
\text { line from third molars }\end{array}$ & unspecified & $\begin{array}{l}\text { During the early stage of inflammation, FoxO3a might regulate } \\
\text { autophagy activation for odontoblast survival. }\end{array}$ & [117] \\
\hline $\begin{array}{l}\text { Mouse odontoblast-like } \\
\text { cells }\end{array}$ & E. coli $\mathrm{L}-2880$ & $\begin{array}{l}\text { Notch signaling activation by LPS stimulation is similar to that } \\
\text { caused by mechanical injury in vivo. }\end{array}$ & {$[52]$} \\
\hline $\begin{array}{l}\text { rat clonal dental pulp } \\
\text { cell line with } \\
\text { odontoblastic properties } \\
\text { (KN-3) }\end{array}$ & $\begin{array}{c}\text { A. } \\
\text { actinomycetemcomitans } \\
\text { ATCC29524 }\end{array}$ & $\begin{array}{c}\text { O3aq directly suppresses the biological effects of LPS on } \\
\text { calcification and immunologic responses of odontoblast-like cells } \\
\text { and its ability to demolish cell walls and cytoplasmic membranes. } \\
\text { O3aq effects may be achieved through the direct inhibition of } \\
\text { lipid A. }\end{array}$ & {$[94]$} \\
\hline $\begin{array}{l}\text { Human Dental Pulp } \\
\text { Tissues; } \\
\text { Odontoblast-like cells, } \\
\text { OLC-1, obtained from } \\
\text { mouse tooth germs }\end{array}$ & P. intermedia & $\begin{array}{l}\text { Upregulated danger signals HMGB1 and RAGE. In response to } \\
\text { HMGB1 stimulation, human microvascular endothelial cells } \\
\text { increase expression of RAGE, cell adhesion molecules, e.g., } \\
\text { ICAM-1 and VCAM-1, and the secretion of TNF } \alpha \text { and IL- } 8 \text {. The } \\
\text { increase of HMGB1 in the cells was blocked by an inhibitor of } \\
\text { IKK- } \beta \text { (TPCA-1). P. intermedia LPS-mediated HMGB1 } \\
\text { translocation involves NF-kB activation in OLC-1. }\end{array}$ & [93] \\
\hline
\end{tabular}

Odontoblast-like cells

from human dental stem cells from the apical papilla (SLMhSCAP) were primarily cultured from extracted third molar dental papilla

Mouse odontoblast-lik
cells
cells

E. coli unspecified
Increased exosome production in odontoblast-like cells generated from mineralization medium-treated hSCAPs. The exosomes showed anti-apoptosis functions. These exosome-dependent intercellular pathways may protect cells from LPS-induced apoptosis.

Abbreviations: LPS—-lipopolysaccharide, IL—interleukins, hDPCs—human dental pulp cells, DPSCs—dental pulp stem cells, NOD/NLRP — nucleotide-binding oligomerization domain-like receptors, NF- $\mathrm{KB}$ - nuclear factor kappa-light-chain-enhancer of activated B cells, HMGB1—high mobility group box 1, RAGE—receptor for advanced glycation end products, PPAR $\gamma$ - peroxisome proliferator-activated receptors $\gamma$, MMPs-matrix metalloproteinases, VCAM - vascular cell adhesion protein, ICAM-intercellular adhesion molecules, TNF- $\alpha$-tumor necrosis factor alpha, AGE-1-, ALP—alkaline phosphatase, OCN—osteocalcin, DSPP—dentin sialophosphoprotein, TET2 - tet methylcytosine dioxygenase 2, ECG—epicatechin gallate, EGCG—epigallocatechin-3-gallate, COX2 - cyclooxygenase-2, IFN-1 $\beta$-interferon-1 $\beta$, ATG-5-autophagy related 5, LC3-I/II-microtubule-associated proteins $1 \mathrm{~A} / 1 \mathrm{~B}$ light chain $3 \mathrm{~B}, \mathrm{HO}-1$-heme oxygenase 1 , PGC-1-peroxisome proliferator-activated receptor gamma coactivator 1-alpha, VEGF-vascular endothelial growth factor, PI3K-phosphoinositide 3-kinases, ERKextracellular signal-regulated kinases, JNK-c-Jun N-terminal kinases, AGGF1-Angiogenic factor with G patch and FHA domains 1, $\gamma$-H2A.X-phosphorylated H2A histone family member X, EB1/5-6-6 bieckol (EB1) and pholorofucofuroeckol-A(EB5), TRAF6 - TNF receptor associated factor, AP-1-Activator protein 1, RUNX-2runt-related transcription factor 2, MEG3 - maternally expressed 3, iNOS-inducible Nitric oxide synthases, OCT4-octamer-binding transcription factor 4, PRFe-platelet-rich fibrin extract, MKP-1-MAPK phosphatase 1 (MKP-1),TRPV1-transient receptor potential cation channel subfamily V member 1, NAC-N-acetylcysteine, 5Aza-CdR-5-Aza-2'-deoxycytidine, DPP-4-Dipeptidyl peptidase-4, MTA-mineral trioxide aggregate, DNMT1DNA (cytosine-5)-methyltransferase 1, m6A-N6-Methyladenosine, METTL3-N6-adenosine-methyltransferase $70 \mathrm{kDa}$ subunit, HIF1 $\alpha$ - hypoxia-inducible factor- $1 \alpha$, SOCS3 - suppressor of cytokine signaling $3, \mathrm{CEBPb}-$ CCAAT enhancer-binding protein beta, $\mathrm{CH} 3 \mathrm{SH}$ - methyl mercaptan, $\mathrm{CCL}-$ chemokine ligand, CXCL chemokine (C-X-C motif) ligand, CXCR-chemokine (C-X-C motif) receptor, G-CSF-granulocyte colony-stimulating factor, GM-CSF — granulocyte-macrophage colony-stimulating factor, $\mathrm{P} 2 \mathrm{X} 7$-P2X purinoceptor 7, ATP—adenosine triphosphate, sEVs—small extracellular vesicles, DMP-1 — dentin matrix acidic phosphoprotein 1, DSB-double strand break, XRCC4-X-ray repair cross-complementing protein 4, NHEJ-non-homologous end joining, HRhomology directed repair, HBD-4-human beta-defensin 4, SLPI—secretory leukocyte protease inhibitor. 
LPS changes the content of small extracellular vesicles (sEVs), promoting dental pulp regeneration by increasing stem cells migration and elevating the expression levels of repair-associated proteins [125]. Exomes isolated from LPS-induced HDPSCs present a stronger pro-angiogenic effect on human umbilical vein endothelial cells (HUVECs) than HDPSCs without LPS stimulation [121]. A time- and dose-dependent increase in VEGFA expression is also noted [126]. In VEGFA-stimulated hDPSCs, FAK, PI3K, Akt and p38 signaling are activated, possibly enhancing cellular migration [126].

Human platelet lysate (HPL) is a growth factors-rich concentrate of platelets. $20 \% \mathrm{HPL}$ increases expression of pro-angiogenic factors at both gene and protein levels, while maintaining the cell viability [127]. In LPS-induced DPSCs simvastatin inhibits the expression of proinflammatory cytokines and VEGF, blocking the MAPK signaling [128]. It also promotes proliferation and apoptosis [128].

\section{Discussion}

In this study, we summarize in vitro research concerning LPS influence on different dental pulp cells. Results show that bacterial endotoxins activate a variety of cellular pathways. Figures 2-5 give an overview of such mechanisms in particular types of cells. We combined data extracted from analyzed studies with information obtained from KEGG database [129]. Despite some structural differences in LPS originating from miscellaneous bacteria species, they are recognized by only two types of TLR receptors-TLR4 and TLR2, which act via the same pathway. Hence, we simplified the graphical presentation of data, not differentiating between various LPS origins. The main response axis in dental cells begins with activation of TLR4/MyD88/NF- $\mathrm{kB}$ pathway, with co-activation of MAP kinases. These pathways are responsible for increasing expression of interleukins, chemokines, MMPs, TNF- $\alpha$ and adhesion molecules. LPS stimulation alters cellular functions in complex ways. Firstly, acting through TLR2/4 receptors, it activates production of inflammatory compounds. Subsequently, gene expression is altered by DNA methylation or expression of microRNAs. LPS also induces autophagy. Finally, LPS stimulation may result in apoptotic or pyroptotic death of affected cells.

An indirect effect of LPS on the inflammation apparatus is exerted by raising ROS production. These factors induce both MAPK and NF-kB pathways, but also inflict DNA damage. This may induce repairing systems or prompt apoptosis, if uncontrolled. Interestingly, agonistic stimulation of PPAR $\gamma$, which is downregulated in LPS-treated cells, can decrease ROS activity [17].

Apart from TLRs, the NLRP system is also involved in signal transduction after exposure to LPS. In selected studies two NLRPs were described-NLRP3 and NLRP6. They both are involved in transducing the signal for Casp1, resulting in pyroptotic cell death.

One of the well-described pathways in hDPCs and odontoblasts is HMGB1 pathway. In LPS-treated cells, the level of HMGB1 is increased. A potential regulator of this protein is microRNA let-7c-5p, which is downregulated by NUTM2A-a particle expressed abundantly after LPS stimulation. HMGB1 through activation of RAGE receptors deteriorates cellular viability and suppresses proliferation.

The analyzed studies present ambiguous results regarding odontoblastic differentiation. On the one hand, authors show results proving that LPS stimulates cells to become odontoblasts [39,61] — an effect regulated by increased levels of DMP-1, DSPP and ALP activity. An alternative pathway mediating this process may be through activation of Wnt5 or AP-1 and MAPK [40]. On the other hand, however, there are several studies with opposing results. Inhibition of Wnt4 pathway or higher expression of dentine-related proteins occurred in cells treated with compounds reducing expression of proinflammatory interleukins $[28,82,124]$. 


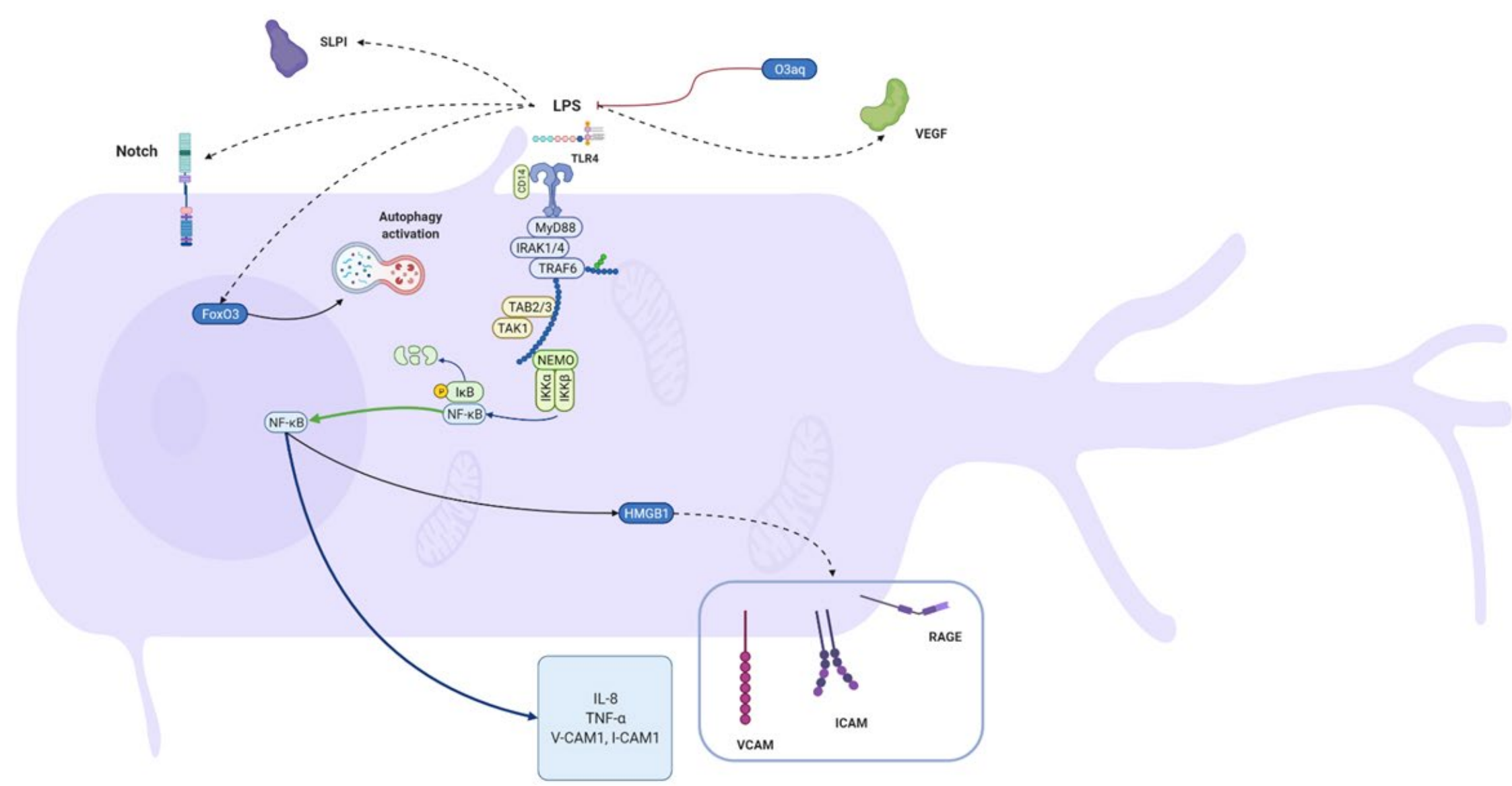

Figure 2. Molecular effects exerted by lipopolysaccharides on odontoblasts. Figure summarizes results from studies conducted on hDPCs, regardless of LPS origin. In odontoblasts a main role in LPS stimulation is played by the TLR/MyD88/NF- $\mathrm{kB}$ pathway. This stimulation results in expression of IL-8, TNF- $\alpha$ and adhesion molecules. A variety of different pathways and particles activated in LPS-treated cells are presented both in deep blue brackets and by protein images with their names. Black arrows represent positive stimulation, dashed arrows show indirect activation, red ones—inhibition, green-translocation to another cell compartment. Created with BioRender.com 7 December 2020. 


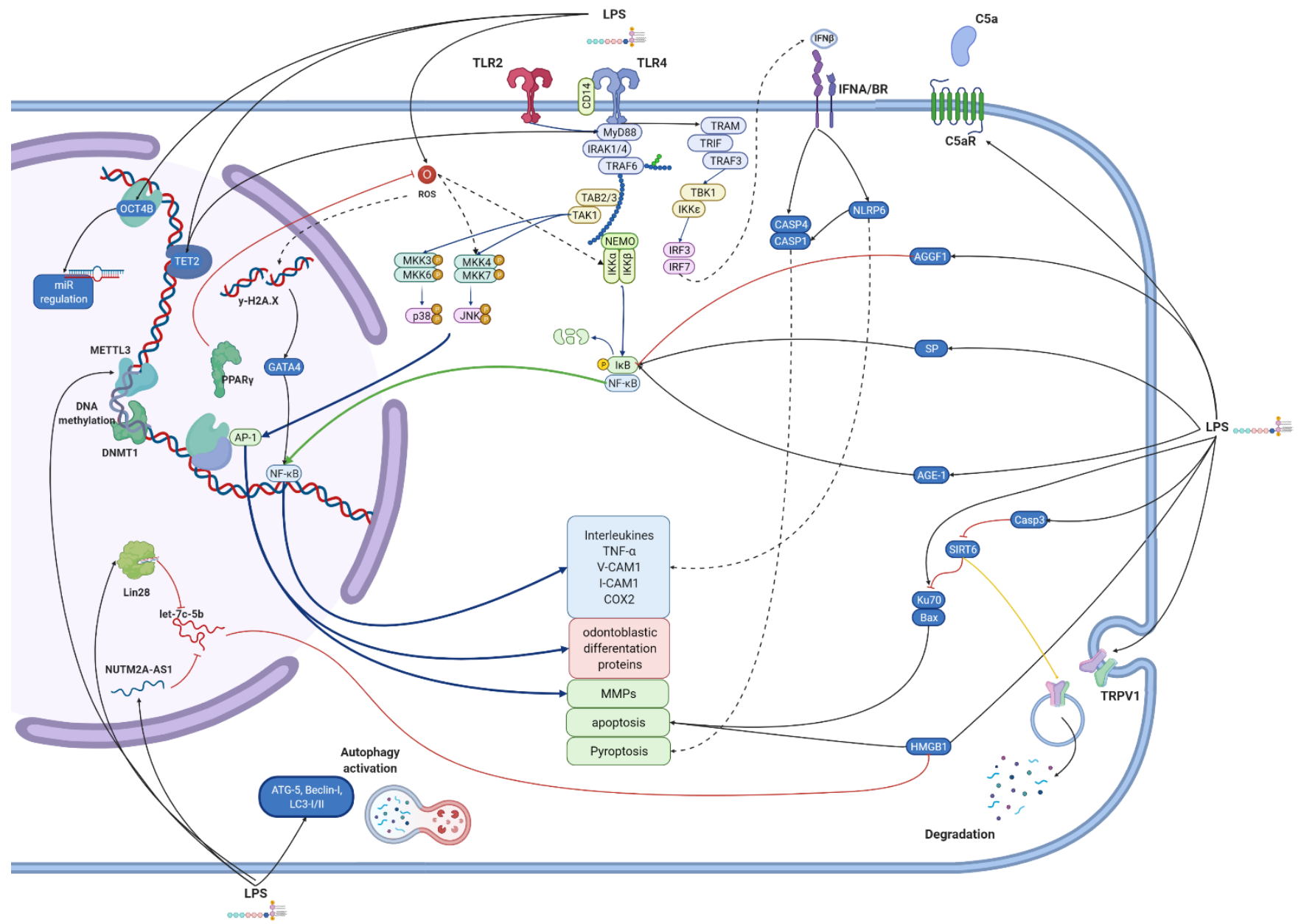

Figure 3. Molecular effects exerted by lipopolysaccharides on human dental pulp cells (hDPCs). Figure summarizes results from studies conducted on hDPCs, regardless of LPS origin. The main pathway activated by LPS involves TLR2/4 receptor. Groups of proteins transducing signal are colored differently. TLR pathway, via NF- $\mathrm{B}$ and MAPK, promotes release of interleukins (mainly IL$1 \beta$, IL-6 and IL-8), adhesive molecules (I-CAM, V-CAM), metalloproteases (MMPs) and odontoblastic differentiation proteins. This pathway is marked with thick blue arrows. LPS increases ROS activity in cells, changes microRNA profile, leads to apoptosis or pyroptosis. A variety of different pathways and particles activated in LPS-treated cells are presented both in deep blue brackets and by protein images with their names. Black arrows represent positive stimulation, dashed arrows show indirect activation, red ones-inhibition, yellow-ubiquitination, green — translocation to another cell compartment. Created with BioRender.com 7 December 2020.

The conclusions of the studies presented above should be interpreted with caution, taking into consideration potential biases. Firstly, there is some uncertainty about cells called hDPCs, which were used in most selected studies. As mentioned in the introduction, dental pulp contains a variety of cell types. In most studies, cell isolation methods did not ascertain the purity of isolated cell lineage. Likely, hDPCs are in fact cohorts of nonhomogenous cells present in the dental pulp. This poses a risk of bias when comparing study results. 


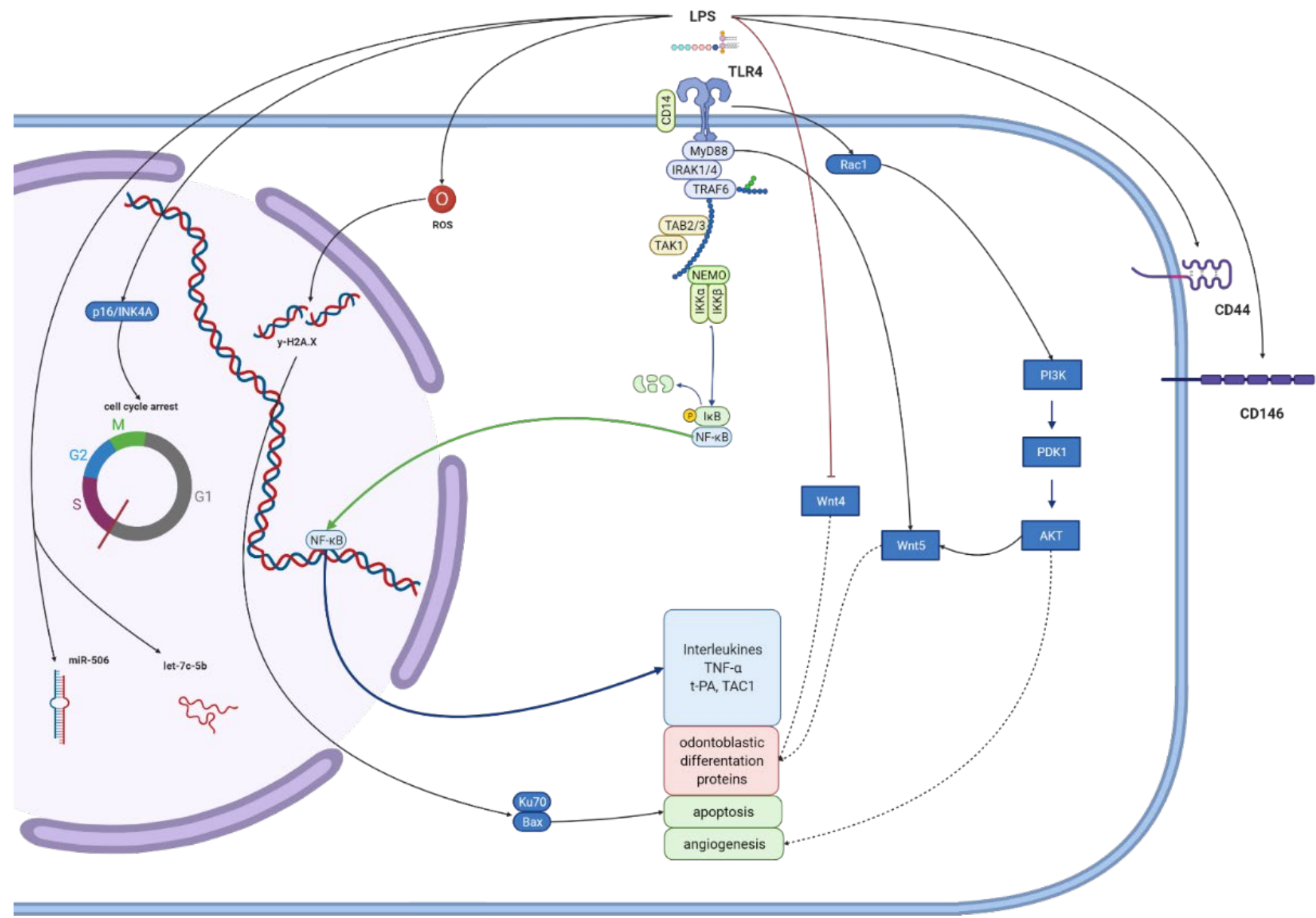

Figure 4. Molecular effects exerted by lipopolysaccharides on dental pulp stem cells (DPSCs). Figure summarizes results from studies conducted on DPSCs, regardless of LPS origin. The main pathway is TLR/MyD88/NF- $\mathrm{kB}$. This pathway is marked with thick blue arrows. Its activation increases interleukins production and odontoblastic differentiation. The last one is also mediated by Wnt $4 / 5$ pathways. LPS stimulation also causes expression of membranous CD44 and CD146. Variety of different pathways and particles activated in LPS-treated cells are presented in both deep blue brackets and by protein images with their names. Black arrows represent positive stimulation, dashed arrows show indirect activation, red ones-inhibition, green-translocation to another cell compartment. Created with BioRender.com 7 December 2020.

Inflammation is a stressful condition, which changes cellular metabolism. It activates a variety of proteins; therefore, it is also important to consider potential bias associated with crosstalk between different pathways. Most studies analyzed only one particle and potential downstream transcriptional molecules. Such an approach does not consider the potential impact of other molecular mechanisms that may have a reciprocal effect on each other. For example, in studies investigating potential anti-inflammatory compounds, a given molecule may activate some transduction pathways, even though it attenuates the inflammation. To ensure the quality of future studies, proper defining of the phenotype of utilized cells should be a standard practice. 


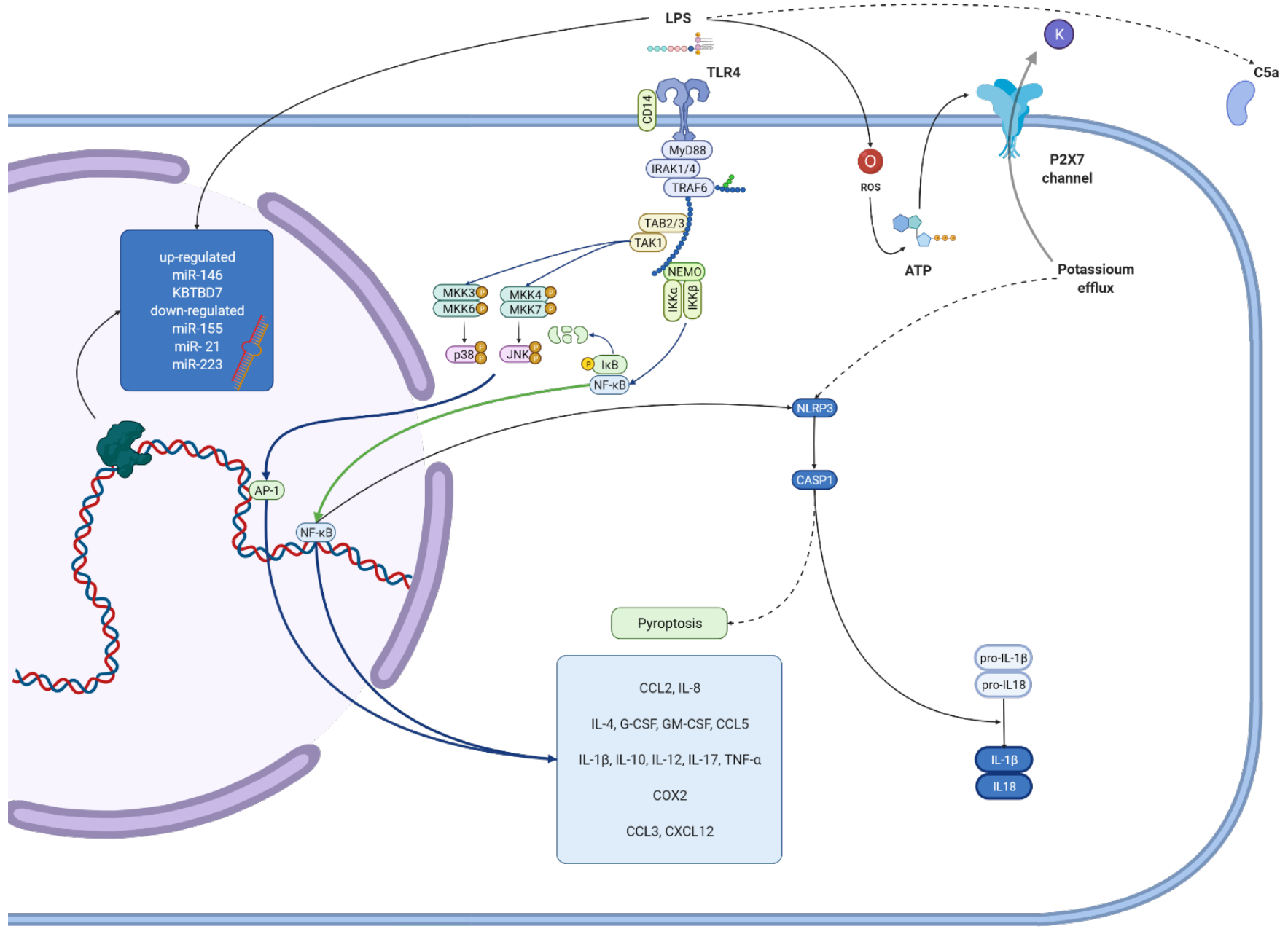

Figure 5. Molecular effects exerted by lipopolysaccharides on fibroblasts Figure summarizes results from studies conducted on fibroblasts, regardless of LPS origin. TLR pathway acts via NF- $\mathrm{B}$ and MAPK, promotes release of interleukins, chemokines and growth factors. Deep blue arrows present this pathway. Pathways and particles activated in LPS-treated cells are presented in both deep blue brackets and by protein images with their names. Black arrows represent positive stimulation, dashed arrows show indirect activation, red ones-inhibition, green-translocation to another cell compartment. Created with BioRender.com 7 December 2020.

\section{Conclusions}

In summary, LPS affects various proinflammatory pathways in pulp cells. The main role is played by TLR receptor activation followed by NF- $\mathrm{kB}$ stimulation. Other important molecules in LPS-stimulated inflammation are NLRs and ROS. Changes in cells treated with LPS are exerted at all levels of expression regulation, from DNA methylation to mRNA post-translational modification.

Supplementary Materials: The following are available online at https://www.mdpi.com/article/ 10.3390/biom12010138/s1, File S1: Systematic review protocol.

Author Contributions: Conceptualization, A.B. and M.K.; methodology M.K. and A.S.; formal analysis, A.S.; investigation, M.C.; resources, M.K.; data curation, M.C.; writing—original draft preparation, M.C. and M.K.; writing-review and editing, A.S. and A.B; visualization, M.K.; supervision, P.K.W. All authors have read and agreed to the published version of the manuscript.

Funding: This research received no external funding.

Conflicts of Interest: Authors declare no conflict of interest. 


\section{References}

1. Park, S.H.; Ye, L.; Love, R.M.; Farges, J.C.; Yumoto, H. Inflammation of the Dental Pulp. Mediat. Inflamm. 2015, $2015,980196$. [CrossRef] [PubMed]

2. Ghannam, M.G.; Alameddine, H.; Bordoni, B. Anatomy, Head and Neck, Pulp (Tooth); StatPearls [Internet]; Updated 11 August 2021; StatPearls Publishing: Treasure Island, FL, USA, January 2022. Available online: https://www.ncbi.nlm.nih.gov/books/NBK537 112/ (accessed on 29 October 2021).

3. Zargar, N.; Ashraf, H.; Marashi, S.M.A.; Sabeti, M.; Aziz, A. Identification of microorganisms in irreversible pulpitis and primary endodontic infections with respect to clinical and radiographic findings. Clin. Oral Investig. 2020, 24, 2099-2108. [CrossRef] [PubMed]

4. Lopez-Marcos, J.F. Aetiology, classification and pathogenesis of pulp and periapical disease. Med. Oral Patol. Oral Cir. Bucal 2004, 9 (Suppl. 58-62), 52-57.

5. Farhana, A.; Khan, Y.S. Biochemistry, Lipopolysaccharide; StatPearls [Internet]; Updated 29 April 2021; StatPearls Publishing: Treasure Island, FL, USA, January 2022. Available online: https://www.ncbi.nlm.nih.gov/books/NBK554414 (accessed on 29 October 2021).

6. Panagakos, F.S. Regulation of pulp cell matrix metalloproteinase production by cytokines and lipopolysaccharides. J. Endod. 1996, 22, 358-361. [CrossRef]

7. Wang, X.X.; Feng, Z.H.; Li, Q.M.; Yi, B.C.; Xu, Q. DNA methylcytosine dioxygenase ten-eleven translocation 2 enhances lipopolysaccharide-induced cytokine expression in human dental pulp cells by regulating MyD88 hydroxymethylation. Cell Tissue Res. 2018, 373, 477-485. [CrossRef]

8. Kong, Q.; Liu, L.; Huang, Y.; Zhang, F.; Wei, X.; Ling, J. The effect of octamer-binding transcription factor 4B1 on microRNA signals in human dental pulp cells with inflammatory response. J. Endod. 2014, 40, 101-108. [CrossRef]

9. Liu, L.; Huang, R.; Yang, R.; Wei, X. OCT4B1 regulates the cellular stress response of human dental pulp cells with inflammation. BioMed Res. Int. 2017, 2017, 2756891. [CrossRef]

10. Cai, L.; Zhan, M.; Li, Q.; Li, D.; Xu, Q. DNA methyltransferase DNMT1 inhibits lipopolysaccharide-induced inflammatory response in human dental pulp cells involving the methylation changes of IL-6 and TRAF6. Mol. Med. Rep. 2020, 21, 959-968. [CrossRef]

11. Feng, Z.; Zhan, M.; Meng, R.; Wang, X.; Xu, Q. 5-Aza-2'-deoxycytidine enhances lipopolysaccharide-induced inflammatory cytokine expression in human dental pulp cells by regulating TRAF6 methylation. Bioengineered 2019, 10, 197-206. [CrossRef]

12. Liu, M.; Chen, L.; Wu, J.; Lin, Z.; Huang, S. Long noncoding RNA MEG3 expressed in human dental pulp regulates LPS-Induced inflammation and odontogenic differentiation in pulpitis. Exp. Cell Res. 2021, 400, 112495. [CrossRef]

13. Wang, X.; Sun, H.; Hu, Z.; Mei, P.; Wu, Y.; Zhu, M. NUTM2A-AS1 silencing alleviates LPS-induced apoptosis and inflammation in dental pulp cells through targeting let-7c-5p/HMGB1 axis. Int. Immunopharmacol. 2021, 96, 107497. [CrossRef]

14. Zhang, X.; Jiang, H.; Gong, Q.; Fan, C.; Huang, Y.; Ling, J. Expression of high mobility group box 1 in inflamed dental pulp and its chemotactic effect on dental pulp cells. Biochem. Biophys. Res. Commun. 2014, 450, 1547-1552. [CrossRef]

15. Nara, K.; Kawashima, N.; Noda, S.; Fujii, M.; Hashimoto, K.; Tazawa, K.; Okiji, T. Anti-inflammatory roles of microRNA 21 in lipopolysaccharide-stimulated human dental pulp cells. J. Cell. Physiol. 2019, 234, 21331-21341. [CrossRef]

16. Mittal, M.; Siddiqui, M.R.; Tran, K.; Reddy, S.P.; Malik, A.B. Reactive oxygen species in inflammation and tissue injury. Antioxid Redox Signal. 2014, 20, 1126-1167. [CrossRef]

17. Kim, J.C.; Lee, Y.H.; Yu, M.K.; Lee, N.H.; Park, J.D.; Bhattarai, G.; Yi, H.K. Anti-inflammatory mechanism of PPAR $\gamma$ on LPS-induced pulp cells: Role of the ROS removal activity. Arch. Oral Biol. 2012, 57, 392-400. [CrossRef]

18. Yu, M.K.; Lee, J.C.; Kim, J.H.; Lee, Y.H.; Jeon, J.G.; Jhee, E.C.; Yi, H.K. Anti-inflammatory Effect of Peroxisome Proliferator Activated Receptor Gamma on Human Dental Pulp Cells. J. Endod. 2009, 35, 524-528. [CrossRef]

19. Wu, H.; He, M.; Yang, R.; Zuo, Y.; Bian, Z. Astrocyte elevated gene-1 participates in the production of pro-inflammatory cytokines in dental pulp cells via NF-KB signalling pathway. Int. Endod. J. 2018, 51, 1130-1138. [CrossRef]

20. Fujii, M.; Kawashima, N.; Tazawa, K.; Hashimoto, K.; Nara, K.; Noda, S.; Nagai, S.; Okiji, T. Hypoxia-inducible factor $1 \alpha$ promotes interleukin $1 \beta$ and tumour necrosis factor $\alpha$ expression in lipopolysaccharide-stimulated human dental pulp cells. Int. Endod. J. 2020, 53, 636-646. [CrossRef]

21. Fujii, M.; Kawashima, N.; Tazawa, K.; Hashimoto, K.; Nara, K.; Noda, S.; Kuramoto, M.; Orikasa, S.; Nagai, S.; Okiji, T. HIF1 $\alpha$ inhibits LPS-mediated induction of IL-6 synthesis via SOCS3-dependent CEBP $\beta$ suppression in human dental pulp cells. Biochem. Biophys. Res. Commun. 2020, 522, 308-314. [CrossRef]

22. Zhang, L.; Bai, L.; Ren, Q.; Sun, G.; Si, Y. Protective effects of SIRT6 against lipopolysaccharide (LPS) are mediated by deacetylation of Ku70. Mol. Immunol. 2018, 101, 312-318. [CrossRef]

23. Takanche, J.S.; Kim, J.S.; Kim, J.E.; Han, S.H.; Yi, H.K. Schisandrin C enhances odontoblastic differentiation through autophagy and mitochondrial biogenesis in human dental pulp cells. Arch. Oral Biol. 2018, 88, 60-66. [CrossRef]

24. Lee, N.H.; Lee, Y.H.; Bhattari, G.; Lee, I.K.; Yun, B.S.; Jeon, J.G.; Hwang, P.H.; Yi, H.K. Reactive oxygen species removal activity of davallialactone reduces lipopolysaccharide-induced pulpal inflammation through inhibition of the extracellular signal-regulated kinase 1/2 and nuclear factor kappa B pathway. J. Endod. 2011, 37, 491-495. [CrossRef]

25. Lee, I.K.; Jung, J.Y.; Seok, S.J.; Kim, W.G.; Yun, B.S. Free radical scavengers from the medicinal mushroom Inonotus xeranticus and their proposed biogenesis. Bioorg. Med. Chem. Lett. 2006, 16, 5621-5624. [CrossRef] 
26. Liu, X.; Cao, Y.; Zhang, Y.; Sun, B.; Liang, H. Teneligliptin inhibits lipopolysaccharide-induced cytotoxicity and inflammation in dental pulp cells. Int. Immunopharmacol. 2019, 73, 57-63. [CrossRef]

27. Weekate, K.; Chuenjitkuntaworn, B.; Chuveera, P.; Vaseenon, S.; Chompu-inwai, P.; Ittichaicharoen, J.; Chattipakorn, S.; Srisuwan, T. Alterations of mitochondrial dynamics, inflammation and mineralization potential of lipopolysaccharide-induced human dental pulp cells after exposure to N-acetyl cysteine, Biodentine or ProRoot MTA. Int. Endod. J. 2021, 54, 951-965. [CrossRef]

28. Liu, Z.; Jiang, T.; Wang, X.; Wang, Y. Fluocinolone acetonide partially restores the mineralization of LPS-stimulated dental pulp cells through inhibition of NF-кB pathway and activation of AP-1 pathway. Br. J. Pharmacol. 2013, 170, 1262-1271. [CrossRef]

29. Wang, Y.Y.; Zhu, N.X.; Zhao, Y.M.; Ge, L.H.; Qin, M. Mineralisation Influence of Betamethasone on Lipopolysaccharide-Stimulated Dental Pulp Cells. Chin. J. Dent. Res. 2019, 22, 123-129. [CrossRef]

30. Jung, J.Y.; Woo, S.M.; Kim, W.J.; Lee, B.N.; Nör, J.E.; Min, K.S.; Choi, C.H.; Koh, J.T.; Lee, K.J.; Hwang, Y.C. Simvastatin inhibits the expression of inflammatory cytokines and cell adhesion molecules induced by LPS in human dental pulp cells. Int. Endod. J. 2017, 50, 377-386. [CrossRef]

31. Cao, R.; Wang, Q.; Wu, J.; Liu, M.; Han, Q.; Wang, X. Nell-1 attenuates lipopolysaccharide-induced inflammation in human dental pulp cells. J. Mol. Histol. 2021, 52, 671-680. [CrossRef]

32. Pavan, R.; Jain, S.; Shraddha; Kumar, A. Properties and therapeutic application of bromelain: A review. Biotechnol. Res. Int. 2012, 2012, 976203. [CrossRef]

33. Hong, J.H.; Kim, M.R.; Lee, B.N.; Oh, W.M.; Min, K.S.; Im, Y.G.; Hwang, Y.C. Anti-inflammatory and mineralization effects of bromelain on lipopolysaccharide-induced inflammation of human dental pulp cells. Medicina 2021, 57, 591. [CrossRef] [PubMed]

34. Lee, J.C.; Yu, M.K.; Lee, R.; Lee, Y.H.; Jeon, J.G.; Lee, M.H.; Jhee, E.C.; Yoo, I.D.; Yi, H.K. Terrein Reduces Pulpal Inflammation in Human Dental Pulp Cells. J. Endod. 2008, 34, 433-437. [CrossRef] [PubMed]

35. Kim, S.J.; Jeong, H.J.; Lee, K.M.; Myung, N.Y.; An, N.H.; Yang, W.M.; Park, S.K.; Lee, H.J.; Hong, S.H.; Kim, H.M.; et al. Epigallocatechin-3-gallate suppresses NF-kappaB activation and phosphorylation of p38 MAPK and JNK in human astrocytoma U373MG cells. J. Nutr. Biochem. 2007, 18, 587-596. [CrossRef] [PubMed]

36. Nakanishi, T.; Mukai, K.; Yumoto, H.; Hirao, K.; Hosokawa, Y.; Matsuo, T. Anti-inflammatory effect of catechin on cultured human dental pulp cells affected by bacteria-derived factors. Eur. J. Oral Sci. 2010, 118, 145-150. [CrossRef]

37. Nakanishi, T.; Mukai, K.; Hosokawa, Y.; Takegawa, D.; Matsuo, T. Catechins inhibit vascular endothelial growth factor production and cyclooxygenase-2 expression in human dental pulp cells. Int. Endod. J. 2015, 48, 277-282. [CrossRef]

38. Songsiripradubboon, S.; Kladkaew, S.; Trairatvorakul, C.; Sangvanich, P.; Soontornvipart, K.; Banlunara, W.; Thunyakitpisal, P. Stimulation of Dentin Regeneration by Using Acemannan in Teeth with Lipopolysaccharide-induced Pulp Inflammation. J. Endod. 2017, 43, 1097-1103. [CrossRef]

39. Huang, Y.; Jiang, H.; Gong, Q.; Li, X.; Ling, J. Lipopolysaccharide stimulation improves the odontoblastic differentiation of human dental pulp cells. Mol. Med. Rep. 2015, 11, 3547-3552. [CrossRef]

40. Sugiuchi, A.; Sano, Y.; Furusawa, M.; Abe, S.; Muramatsu, T. Human Dental Pulp Cells Express Cellular Markers for Inflammation and Hard Tissue Formation in Response to Bacterial Information. J. Endod. 2018, 44, 992-996. [CrossRef]

41. Colombini-Ishikiriama, B.L.; Dionisio, T.J.; Garbieri, T.F.; da Silva, R.A.; Machado, M.; de Oliveira, S.H.P.; Lara, V.S.; Greene, A.S.; Santos, C.F. What is the response profile of deciduous pulp fibroblasts stimulated with E. coli LPS and E. faecalis LTA? BMC Immunol. 2020, 21, 38. [CrossRef]

42. Coil, J.; Tam, E.; Waterfield, J.D. Proinflammatory cytokine profiles in pulp fibroblasts stimulated with lipopolysaccharide and methyl mercaptan. J. Endod. 2004, 30, 88-91. [CrossRef]

43. Jiang, W.; Lv, H.; Wang, H.; Wang, D.; Sun, S.; Jia, Q.; Wang, P.; Song, B.; Ni, L. Activation of the NLRP3/caspase-1 inflammasome in human dental pulp tissue and human dental pulp fibroblasts. Cell Tissue Res. 2015, 361, 541-555. [CrossRef]

44. Zhang, A.; Wang, P.; Ma, X.; Yin, X.; Li, J.; Wang, H.; Jiang, W.; Jia, Q.; Ni, L. Mechanisms that lead to the regulation of NLRP3 inflammasome expression and activation in human dental pulp fibroblasts. Mol. Immunol. 2015, 66, 253-262. [CrossRef] [PubMed]

45. Kantrong, N.; Jit-Armart, P.; Arayatrakoollikit, U. Melatonin antagonizes lipopolysaccharide-induced pulpal fibroblast responses. BMC Oral Health 2020, 20, 91. [CrossRef]

46. Nagaoka, S.; Tokuda, M.; Sakuta, T.; Taketoshi, Y.; Tamura, M.; Takada, H.; Kawagoe, M. Interleukin-8 gene expression by human dental pulp fibroblast in cultures stimulated with Prevotella intermedia lipopolysaccharide. J. Endod. 1996, 22, 9-12. [CrossRef]

47. Takahashi, K.; Nakanishi, T.; Yumoto, H.; Adachi, T.; Matsuo, T. CCL20 production is induced in human dental pulp upon stimulation by Streptococcus mutans and proinflammatory cytokines. Oral Microbiol. Immunol. 2008, 23, 320-327. [CrossRef]

48. Song, J.; Wu, Q.; Jiang, J.; Sun, D.; Wang, F.; Xin, B.; Cui, Q. Berberine reduces inflammation of human dental pulp fibroblast via miR-21/KBTBD7 axis. Arch. Oral Biol. 2020, 110, 104630. [CrossRef]

49. Botero, T.M.; Shelburne, C.E.; Holland, G.R.; Hanks, C.T.; Nör, J.E. TLR4 Mediates LPS-Induced VEGF Expression in Odontoblasts. J. Endod. 2006, 32, 951-955. [CrossRef]

50. Levin, L.G.; Rudd, A.; Bletsa, A.; Reisner, H. Expression of IL-8 by cells of the odontoblast layer in vitro. Eur. J. Oral Sci. 1999, 107, 131-137. [CrossRef]

51. Choi, B.D.; Jeong, S.J.; Wang, G.; Kim, H.J.; Kim, B.O.; Hwang, H.K.; Lim, D.S.; Kim, S.H.; Jeong, M.J. Temporal Induction of Secretory Leukocyte Protease Inhibitor (SLPI) in Odontoblasts by Lipopolysaccharide and Wound Infection. J. Endod. 2009, 35, 997-1002. [CrossRef] 
52. Ma, L.; Wang, S.C.; Tong, J.; Hu, Y.; Zhang, Y.Q.; Yu, Q. Activation and dynamic expression of Notch signalling in dental pulp cells after injury in vitro and in vivo. Int. Endod. J. 2016, 49, 1165-1174. [CrossRef]

53. Neiva, K.G.; Catalfamo, D.L.; Holliday, L.S.; Wallet, S.M.; Pileggi, R. Propolis decreases lipopolysaccharide-induced inflammatory mediators in pulp cells and osteoclasts. Dent. Traumatol. 2014, 30, 362-367. [CrossRef] [PubMed]

54. Liao, C.; Wang, Y.; Ou, Y.; Wu, Y.; Zhou, Y.; Liang, S. Effects of sclerostin on lipopolysaccharide-induced inflammatory phenotype in human odontoblasts and dental pulp cells. Int. J. Biochem. Cell Biol. 2019, 117, 105628. [CrossRef] [PubMed]

55. Bindal, P.; Ramasamy, T.S.; Kasim, N.H.A.; Gnanasegaran, N.; Chai, W.L. Immune responses of human dental pulp stem cells in lipopolysaccharide-induced microenvironment. Cell Biol. Int. 2018, 42, 832-840. [CrossRef] [PubMed]

56. Widbiller, M.; Eidt, A.; Wölflick, M.; Lindner, S.R.; Schweikl, H.; Hiller, K.A.; Buchalla, W.; Galler, K.M. Interactive effects of LPS and dentine matrix proteins on human dental pulp stem cells. Int. Endod. J. 2018, 51, 877-888. [CrossRef]

57. Lee, S.; Zhang, Q.Z.; Karabucak, B.; Le, A.D. DPSCs from inflamed pulp modulate macrophage function via the TNF- $\alpha /$ IDO axis. J. Dent. Res. 2016, 95, 1274-1281. [CrossRef]

58. He, W.; Wang, Z.; Zhou, Z.; Zhang, Y.; Zhu, Q.; Wei, K.; Lin, Y.; Cooper, P.R.; Smith, A.J.; Yu, Q. Lipopolysaccharide enhances Wnt5a expression through toll-like receptor 4, myeloid differentiating factor 88, phosphatidylinositol 3-OH kinase/AKT and nuclear factor kappa B pathways in human dental pulp stem cells. J. Endod. 2014, 40, 69-75. [CrossRef]

59. Ning, T.; Shao, J.; Zhang, X.; Luo, X.; Huang, X.; Wu, H.; Xu, S.; Wu, B.; Ma, D. Ageing affects the proliferation and mineralization of rat dental pulp stem cells under inflammatory conditions. Int. Endod. J. 2020, 53, 72-83. [CrossRef]

60. Yuan, H.; Zhao, H.; Wang, J.; Zhang, H.; Hong, L.; Li, H.; Che, H.; Zhang, Z. MicroRNA let-7c-5p promotes osteogenic differentiation of dental pulp stem cells by inhibiting lipopolysaccharide-induced inflammation via HMGA2/PI3K/Akt signal blockade. Clin. Exp. Pharmacol. Physiol. 2019, 46, 389-397. [CrossRef]

61. He, W.X.; Wang, Z.H.; Luo, Z.R.; Yu, Q.; Jiang, Y.; Zhang, Y.Q.; Zhou, Z.Y.; Smith, A.J.; Cooper, P.R. LPS Promote the Odontoblastic Differentiation of Human Dental Pulp Stem Cells via MAPK Signaling Pathway. J. Cell. Physiol. 2015, 230, 554-561. [CrossRef]

62. Chen, W.; Guan, Y.; Xu, F.; Jiang, B. 4-Methylumbelliferone promotes the migration and odontogenetic differentiation of human dental pulp stem cells exposed to lipopolysaccharide in vitro. Cell Biol. Int. 2021, 45, 1415-1422. [CrossRef]

63. Gong, Q.M.; Quan, J.J.; Jiang, H.W.; Ling, J.Q. Regulation of the stromal cell-derived factor- $1 \alpha-C X C R 4$ axis in human dental pulp cells. J. Endod. 2010, 36, 1499-1503. [CrossRef]

64. Feng, X.; Feng, G.; Xing, J.; Shen, B.; Tan, W.; Huang, D.; Lu, X.; Tao, T.; Zhang, J.; Li, L.; et al. Repeated lipopolysaccharide stimulation promotes cellular senescence in human dental pulp stem cells (DPSCs). Cell Tissue Res. 2014, 356, 369-380. [CrossRef]

65. Feng, G.; Zheng, K.; Cao, T.; Zhang, J.; Lian, M.; Huang, D.; Wei, C.; Gu, Z.; Feng, X. Repeated stimulation by LPS promotes the senescence of DPSCs via TLR4/MyD88-NF-kB-p53/p21 signaling. Cytotechnology 2018, 70, 1023-1035. [CrossRef]

66. Huang, Y.; Qiao, W.; Wang, X.; Gao, Q.; Peng, Y.; Bian, Z.; Meng, L. Role of Ku70 in the apoptosis of inflamed dental pulp stem cells. Inflamm. Res. 2018, 67, 777-788. [CrossRef]

67. Li, Y.; Zhao, Y.; Han, J.; Wang, Y.; Lei, S. Effects of epigallocatechin gallate (EGCG) on the biological properties of human dental pulp stem cells and inflammatory pulp tissue. Arch. Oral Biol. 2021, 123, 105034. [CrossRef]

68. Wang, D.; Zhu, N.X.; Qin, M.; Wang, Y.Y. Betamethasone suppresses the inflammatory response in LPS-stimulated dental pulp cells through inhibition of NF-kB. Arch. Oral Biol. 2019, 98, 156-163. [CrossRef]

69. Soares, D.G.; Zhang, Z.; Mohamed, F.; Eyster, T.W.; de Souza Costa, C.A.; Ma, P.X. Simvastatin and nanofibrous poly(L-lactic acid) scaffolds to promote the odontogenic potential of dental pulp cells in an inflammatory environment. Acta Biomater. 2018, 68, 190-203. [CrossRef]

70. Mo, Z.; Li, Q.; Cai, L.; Zhan, M.; Xu, Q. The effect of DNA methylation on the miRNA expression pattern in lipopolysaccharideinduced inflammatory responses in human dental pulp cells. Mol. Immunol. 2019, 111, 11-18. [CrossRef]

71. Sipert, C.R.; Morandini, A.C.; Dionisio, T.J.; Trachtenberg, A.J.; Kuo, W.P.; Santos, C.F. MicroRNA-146a and microRNA-155 show tissue-dependent expression in dental pulp, gingival and periodontal ligament fibroblasts in vitro. J. Oral Sci. 2014, 56, 157-164. [CrossRef]

72. Feng, Z.; Li, Q.; Meng, R.; Yi, B.; Xu, Q. METTL3 regulates alternative splicing of MyD88 upon the lipopolysaccharide-induced inflammatory response in human dental pulp cells. J. Cell. Mol. Med. 2018, 22, 2558-2568. [CrossRef]

73. Tian, X.X.; Li, R.; Liu, C.; Liu, F.; Yang, L.J.; Wang, S.P.; Wang, C.L. NLRP6-caspase 4 inflammasome activation in response to cariogenic bacterial lipoteichoic acid in human dental pulp inflammation. Int. Endod. J. 2021, 54, 916-925. [CrossRef] [PubMed]

74. Feng, Q.; Sun, X.; Ren, Q.; Liu, J. Protective effect of SIRT6 against LPS-induced human dental pulp cell apoptosis via regulating Ku70 deacetylation. Int. J. Clin. Exp. Pathol. 2017, 10, 72-79.

75. Shin, M.R.; Kang, S.K.; Kim, Y.S.; Lee, S.Y.; Hong, S.C.; Kim, E.C. TNF- $\alpha$ and LPS activate angiogenesis via VEGF and SIRT1 signalling in human dental pulp cells. Int. Endod. J. 2015, 48, 705-716. [CrossRef] [PubMed]

76. Lee, S.I.; Kang, S.K.; Jung, H.J.; Chun, Y.H.; Kwon, Y.D.; Kim, E.C. Muramyl dipeptide activates human beta defensin 2 and pro-inflammatory mediators through Toll-like receptors and NLRP3 inflammasomes in human dental pulp cells. Clin. Oral Investig. 2015, 19, 1419-1428. [CrossRef]

77. Lee, S.A.; Kim, B.R.; Kim, B.K.; Kim, D.W.; Shon, W.J.; Lee, N.R.; Inn, K.S.; Kim, B.J. Heat shock protein-mediated cell penetration and cytosolic delivery of macromolecules by a telomerase-derived peptide vaccine. Biomaterials 2013, 34, 7495-7505. [CrossRef] [PubMed] 
78. Ko, Y.J.; Kwon, K.Y.; Kum, K.Y.; Lee, W.C.; Baek, S.H.; Kang, M.K.; Shon, W.J. The Anti-Inflammatory Effect of Human TelomeraseDerived Peptide on P. gingivalis Lipopolysaccharide-Induced Inflammatory Cytokine Production and Its Mechanism in Human Dental Pulp Cells. Mediat. Inflamm. 2015, 2015, 385127. [CrossRef]

79. Wang, F.; Han, Y.; Xi, S.; Lu, Y. Catechins reduce inflammation in lipopolysaccharide-stimulated dental pulp cells by inhibiting activation of the NF-kB pathway. Oral Dis. 2020, 26, 815-821. [CrossRef]

80. Kim, D.S.; Shin, M.R.; Kim, Y.S.; Bae, W.J.; Roh, D.H.; Hwang, Y.S.; Kim, E.C. Anti-inflammatory effects of glutamine on LPS-stimulated human dental pulp cells correlate with activation of MKP-1 and attenuation of the MAPK and NF- $\mathrm{B}$ pathways. Int. Endod. J. 2015, 48, 220-228. [CrossRef]

81. Choukroun, J.; Diss, A.; Simonpieri, A.; Girard, M.O.; Schoeffler, C.; Dohan, S.L.; Dohan, A.J.; Mouhyi, J.; Dohan, D.M. Platelet-rich fibrin (PRF): A second-generation platelet concentrate. Part IV: Clinical effects on tissue healing. Oral Surg. Oral Med. Oral Pathol. Oral Radiol. Endod. 2006, 101, e56-e60. [CrossRef]

82. Kim, J.H.; Woo, S.M.; Choi, N.K.; Kim, W.J.; Kim, S.M.; Jung, J.Y. Effect of Platelet-rich Fibrin on Odontoblastic Differentiation in Human Dental Pulp Cells Exposed to Lipopolysaccharide. J. Endod. 2017, 43, 433-438. [CrossRef]

83. Galicia, J.C.; Naqvi, A.R.; Ko, C.C.; Nares, S.; Khan, A.A. MiRNA-181a regulates Toll-like receptor agonist-induced inflammatory response in human fibroblasts. Genes Immun. 2014, 15, 333-337. [CrossRef]

84. Sipert, C.R.; Morandini, A.C.F.; Modena, K.C.S.; Dionisio, T.J.; Machado, M.A.A.M.; de Oliveira, S.H.P.; Campanelli, A.P.; Santos, C.F. CCL3 and CXCL12 production in vitro by dental pulp fibroblasts from permanent and deciduous teeth stimulated by Porphyromonas gingivalis LPS. J. Appl. Oral Sci. 2013, 21, 99-105. [CrossRef]

85. Chang, J.; Zhang, C.; Tani-Ishii, N.; Shi, S.; Wang, C.Y. NF-кB activation in human dental pulp stem cells by TNF and LPS. J. Dent. Res. 2005, 84, 994-998. [CrossRef]

86. Nakane, A.; Yoshida, T.; Nakata, K.; Horiba, N.; Nakamura, H. Effects of lipopolysaccharides on human dental pulp cells. J. Endod. 1995, 21, 128-130. [CrossRef]

87. Hosoya, S.; Matsushima, K. Stimulation of interleukin-1 $\beta$ production of human dental pulp cells by Porphyromonas endodontalis lipopolysaccharide. J. Endod. 1997, 23, 39-42. [CrossRef]

88. Lu, H.X.; Xiao, M.Z.; Niu, Z.Y.; Guo, X.M.; Zhao, S.L.; Wang, H.G.; Guo, H.Y. Effect of IL-1ra on human dental pulp cells and pulpal inflammation. Int. Endod. J. 2002, 35, 807-811. [CrossRef]

89. Tokuda, M. Regulation of interleukin-6 expression in human dental pulp cell cultures stimulated with prevotella intermedia lipopolysaccharide. J. Endod. 2001, 27, 273-277. [CrossRef]

90. Tokuda, M.; Miyamoto, R.; Nagaoka, S.; Torii, M. Substance P enhances expression of lipopolysaccharide-induced inflammatory factors in dental pulp cells. J. Endod. 2004, 30,770-774. [CrossRef]

91. Matsushita, K.; Motani, R.; Sakuta, T.; Nagaoka, S.; Matsuyama, T.; Abeyama, K.; Maruyama, I.; Takada, H.; Torii, M. Lipopolysaccharide enhances the production of vascular endothelial growth factor by human pulp cells in culture. Infect. Immun. 1999, 67, 1633-1639. [CrossRef]

92. Modena, K.C.S.; Calvo, A.M.; Sipert, C.R.; Dionísio, T.J.; Navarro, M.F.L.; Atta, M.T.; Dos Santos, C.F. Dental pulp fibroblasts response after stimulation with hema and adhesive system. Braz. Dent. J. 2018, 29, 419-426. [CrossRef]

93. Tancharoen, S.; Tengrungsun, T.; Suddhasthira, T.; Kikuchi, K.; Vechvongvan, N.; Tokuda, M.; Maruyama, I. Overexpression of receptor for advanced glycation end products and high-mobility group box 1 in human dental pulp inflammation. Mediat. Inflamm. 2014, 2014, 754069. [CrossRef] [PubMed]

94. Noguchi, F.; Kitamura, C.; Nagayoshi, M.; Chen, K.K.; Terashita, M.; Nishihara, T. Ozonated Water Improves LipopolysaccharideInduced Responses of an Odontoblast-like Cell Line. J. Endod. 2009, 35, 668-672. [CrossRef] [PubMed]

95. Hsieh, S.C.; Tsao, J.T.; Lew, W.Z.; Chan, Y.H.; Lee, L.W.; Lin, C.T.; Huang, Y.K.; Huang, H.M. Static magnetic field attenuates lipopolysaccharide-induced inflammation in pulp cells by affecting cell membrane stability. Sci. World J. 2015, $2015,492683$. [CrossRef] [PubMed]

96. Qiao, W.; Huang, Y.; Bian, Z.; Sun, X.; Wang, X.; Gao, Q.; Peng, Y.; Meng, L. Lipopolysaccharide-induced DNA damage response activates nuclear factor $\mathrm{KB}$ signalling pathway via GATA4 in dental pulp cells. Int. Endod. J. 2019, 52, 1704-1715. [CrossRef]

97. Liu, Y.; Dong, N.; Li, J.; Zhao, L.; Gao, L.; Zhang, Y.; Ruan, J. RNA-binding protein Lin28 is associated with injured dentin-dental pulp complex in Sprague-Dawley rats. Int. J. Clin. Exp. Pathol. 2018, 11, 4385-4394.

98. Jun-Hao, E.T.; Gupta, R.R.; Shyh-Chang, N. Lin28 and let-7 in the Metabolic Physiology of Aging. Trends Endocrinol. Metab. 2016, 27, 132-141. [CrossRef]

99. Zhao, Y.; Chen, L.; Shen, Z.; Li, J.; Huang, S.; Wang, R.; Lin, Z.; Song, Z. Expression of nucleotide-binding oligomerization domain-like receptor family pyrin domain containing 6 in human dental pulp tissues and cells. Arch. Oral Biol. 2020, 117, 104794. [CrossRef]

100. Liu, M.; Mu, H.; Peng, W.; Zhao, L.; Hu, W.; Jiang, Z.; Gao, L.; Cao, X.; Li, N.; Han, J. Time-dependent C5a and C5aR expression in dental pulp cells following stimulation with LTA and LPS. Int. J. Mol. Med. 2019, 44, 823-834. [CrossRef]

101. Kawai, S.; Harada, K.; Daito, K.; Arita, K.; Ohura, K. Tnf- $\alpha$ and LPS enhance MMP production in human dental pulp cells of deciduous teeth. J. Hard Tissue Biol. 2012, 21, 151-156. [CrossRef]

102. Shen, S.; Shang, L.; Liu, H.; Liang, Q.; Liang, W.; Ge, S. AGGF1 inhibits the expression of inflammatory mediators and promotes angiogenesis in dental pulp cells. Clin. Oral Investig. 2021, 25, 581-592. [CrossRef] 
103. Sun, G.; Ren, Q.; Bai, L.; Zhang, L. Phoenixin-20 suppresses lipopolysaccharide-induced inflammation in dental pulp cells. Chem.-Biol. Interact. 2020, 318, 108971. [CrossRef]

104. Yosten, G.L.; Lyu, R.M.; Hsueh, A.J.; Avsian-Kretchmer, O.; Chang, J.K.; Tullock, C.W.; Dun, S.L.; Dun, N.; Samson, W.K. A novel reproductive peptide, phoenixin. J. Neuroendocr. 2013, 25, 206-215. [CrossRef]

105. Huang, Y.; Li, X.; Liu, Y.; Gong, Q.; Tian, J.; Jiang, H. LPS-induced autophagy in human dental pulp cells is associated with p38. J. Mol. Histol. 2021, 5, 919-928. [CrossRef]

106. Gao, Y.; You, X.; Liu, Y.; Gao, F.; Zhang, Y.; Yang, J.; Yang, C. Induction of autophagy protects human dental pulp cells from lipopolysaccharide-induced pyroptotic cell death. Exp. Med. 2020, 19, 2202-2210. [CrossRef]

107. Hu, J.; Chen, W.; Qiu, Z.; Lv, H. Robust expression of SIRT6 inhibits pulpitis via activation of the TRPV1 channel. Cell Biochem. Funct. 2020, 38, 676-682. [CrossRef]

108. Paudel, U.; Lee, Y.H.; Kwon, T.H.; Park, N.H.; Yun, B.S.; Hwang, P.H.; Yi, H.K. Eckols reduce dental pulp inflammation through the ERK1/2 pathway independent of COX-2 inhibition. Oral Dis. 2014, 20, 827-832. [CrossRef]

109. Liu, L.; Shu, S.; Cheung, G.S.; Wei, X. Effect of miR-146a/bFGF/PEG-PEI Nanoparticles on Inflammation Response and Tissue Regeneration of Human Dental Pulp Cells. BioMed Res. Int. 2016, 2016, 3892685. [CrossRef]

110. Guo, X.; Chen, J. The protective effects of saxagliptin against lipopolysaccharide (LPS)-induced inflammation and damage in human dental pulp cells. Artif. Cells Nanomed. Biotechnol. 2019, 47, 1288-1294. [CrossRef]

111. Lai, W.Y.; Kao, C.T.; Hung, C.J.; Huang, T.H.; Shie, M.Y. An evaluation of the inflammatory response of lipopolysaccharide-treated primary dental pulp cells with regard to calcium silicate-based cements. Int. J. Oral Sci. 2014, 6, 94-98. [CrossRef]

112. Wang, M.C.; Tu, H.F.; Chang, K.W.; Lin, S.C.; Yeh, L.Y.; Hung, P.S. The molecular functions of Biodentine and mineral trioxide aggregate in lipopolysaccharide-induced inflamed dental pulp cells. Int. Endod. J. 2021, 54, 1317-1327. [CrossRef]

113. Yang, G.; Ju, Y.; Liu, S.; Zhao, S. Lipopolysaccharide upregulates the proliferation, migration, and odontoblastic differentiation of NG2+ cells from human dental pulp in vitro. Cell Biol. Int. 2019, 43, 1276-1285. [CrossRef]

114. Chmilewsky, F.; Jeanneau, C.; Laurent, P.; About, I. LPS induces pulp progenitor cell recruitment via complement activation. J. Dent. Res. 2015, 94, 166-174. [CrossRef]

115. Liu, Y.; Zhang, Z.; Li, W.; Tian, S. PECAM1 Combines With CXCR4 to Trigger Inflammatory Cell Infiltration and Pulpitis Progression Through Activating the NF-kB Signaling Pathway. Front. Cell Dev. Biol. 2020, 8, 1694. [CrossRef]

116. Wang, D.; Sun, S.; Xue, Y.; Qiu, J.; Ye, T.; Zhang, R.; Song, B.; He, W.; Zhang, Y.; Jiang, W. MicroRNA-223 negatively regulates LPS-induced inflammatory responses by targeting NLRP3 in human dental pulp fibroblasts. Int. Endod. J. 2021, 54, 241-254. [CrossRef]

117. Li, Y.; Wang, H.; Pei, F.; Chen, Z.; Zhang, L. FoxO3a Regulates Inflammation-induced Autophagy in Odontoblasts. J. Endod. 2018, 44, 786-791. [CrossRef]

118. Wang, H.S.; Yang, F.H.; Wang, Y.J.; Pei, F.; Chen, Z.; Zhang, L. Odontoblastic Exosomes Attenuate Apoptosis in Neighboring Cells. J. Dent. Res. 2019, 98, 1271-1278. [CrossRef]

119. He, Q.; Wang, H.; Fan, M.; Zhang, L.; Huang, S.; Li, Y. Activation of autophagy in pulpitis is associated with TLR4. Int. J. Clin. Exp. Pathol. 2017, 10, 4488-4496.

120. Yuan, H.; Zhang, H.; Hong, L.; Zhao, H.; Wang, J.; Li, H.; Che, H.; Zhang, Z. MicroRNA let-7c-5p suppressed lipopolysaccharideinduced dental pulp inflammation by inhibiting dentin matrix protein-1-mediated nuclear factor kappa $\mathrm{b}(\mathrm{NF}-\mathrm{kb}) \mathrm{pathway}$ in vitro and in vivo. Med. Sci. Monit. 2018, 24, 6656-6665. [CrossRef]

121. Huang, X.; Qiu, W.; Pan, Y.; Li, J.; Chen, Z.; Zhang, K.; Luo, Y.; Wu, B.; Xu, W. Exosomes from LPS-Stimulated hDPSCs Activated the Angiogenic Potential of HUVECs in Vitro. Stem Cells Int. 2021, 2021, 6685307. [CrossRef]

122. Wang, J.; Du, Y.; Deng, J.; Wang, X.; Long, F.; He, J. MicroRNA-506 is involved in regulation of the occurrence of lipopolysaccharides (LPS)-induced pulpitis by sirtuin 1 (SIRT1). Med. Sci. Monit. 2019, 25, 10008-10015. [CrossRef]

123. Zhai, Y.; Yuan, X.; Zhao, Y.; Ge, L.; Wang, Y. Potential Application of Human $\beta$-Defensin 4 in Dental Pulp Repair. Front. Physiol. 2020, 11, 1077. [CrossRef] [PubMed]

124. Zhong, T.Y.; Zhang, Z.C.; Gao, Y.N.; Lu, Z.; Qiao, H.; Zhou, H.; Liu, Y. Loss of Wnt4 expression inhibits the odontogenic potential of dental pulp stem cells through JNK signaling in pulpitis. Am. J. Transl. Res. 2019, 11, 1819-1826. [PubMed]

125. Chen, W.J.; Xie, J.; Lin, X.; Ou, M.H.; Zhou, J.; Wei, X.L.; Chen, W.X. The Role of Small Extracellular Vesicles Derived from Lipopolysaccharide-preconditioned Human Dental Pulp Stem Cells in Dental Pulp Regeneration. J. Endod. 2021, 47, 961-969. [CrossRef] [PubMed]

126. Sun, X.; Meng, L.; Qiao, W.; Yang, R.; Gao, Q.; Peng, Y.; Bian, Z. Vascular endothelial growth factor A/Vascular endothelial growth factor receptor 2 axis promotes human dental pulp stem cell migration via the FAK/PI3K/Akt and p38 MAPK signalling pathways. Int. Endod. J. 2019, 52, 1691-1703. [CrossRef] [PubMed]

127. Bindal, P.; Gnanasegaran, N.; Bindal, U.; Haque, N.; Ramasamy, T.S.; Chai, W.L.; Kasim, N.H.A. Angiogenic effect of platelet-rich concentrates on dental pulp stem cells in inflamed microenvironment. Clin. Oral Investig. 2019, 23, 3821-3831. [CrossRef] [PubMed] 
128. Xue, D.; Gong, Z.; Zhu, F.; Qiu, Y.; Li, X. Simvastatin increases cell viability and suppresses the expression of cytokines and vascular endothelial growth factor in inflamed human dental pulp stem cells in vitro. Adv. Clin. Exp. Med. 2018, 27, 1615-1623. [CrossRef]

129. Kyoto Encyclopedia of Genes and Genomes. Available online: https:/ / www.genome.jp/kegg/pathway.html (accessed on 29 October 2021). 